\title{
TRÁFICO E INTERACCIÓN ENTRE EL OASIS DE PICA Y LA COSTA ARREICA EN EL DESIERTO TARAPAQUEÑO (NORTE DE CHILE)
}

\author{
TRAFFIC AND INTERACTION BETWEEN OASIS OF PICA AND THE COAST IN THE \\ ATACAMA DESERT (NORTHERN CHILE).
}

\author{
Lautaro Núñez A. ${ }^{1}$ y Luis Briones M. ${ }^{2}$
}

\begin{abstract}
Resumen
Se plantea un micro análisis espacial para evaluar la movilidad de recursos entre los asentamientos de los valles endorreicos y los enclaves del litoral arreico durante el periodo Intermedio Tardío, a través del tráfico caravanero intermodal en el desierto central de Atacama. En un marco de armonía social,

la circulación vial asociada a ritos geo-simbólicos caracterizó a estos asentamientos "insulares" a través de grupos que ejercieron permanencias prolongadas con retorno a sus cabeceras. La territorialidad del Complejo Pica-Tarapacá incorporó nodos productivos en el Pacífico aledaño a través de circuitos asociados a sitios domésticos y rituales inter asentamientos. Se describen los indicadores de movilidad: materialidades, campamentos, dietas, contextos funerarios y ritos rupestres que establecen conexiones entre los cementerios del oasis de Pica, los campamentos intermediarios de Pintados, Soronal y los cementerios costeros de Patillos y Bajo Molle. Se concluye que segmentos de la población del oasis de Pica intensificaron los traslados por pasajes estériles de interfluvio, en donde ejercieron permanencias temporales en coexistencia con las poblaciones locales, moviendo excedentes alimentarios terrestres y marítimos. La complejidad de estas operaciones indicaría la vigencia de liderazgo sociopolítico local controlado y ampliado durante el régimen incaico.
\end{abstract}

Palabras claves: Tráfico de recursos - oasis costa arreica movilidad internodal - periodo Intermedio Tardío.

A micro spatial analysis is proposed to evaluate the circulation of resources between endorheic valleys settlements and coastal desert enclaves, through the caravan intermodal traffic in the Atacama Desert during the Late Intermediate Period. Within a harmonious social context, road circulation associated with geo-symbolic rites characterized these "island" settlements. While occupying permanent home bases, these groups also practiced longterm halts along these roads. The Pica-Tarapacá Complex's territoriality incorporated productive nodes in the Pacific through circuits associated with domestic sites and inter settlements rituals. We describe mobility indicators: materialities, camps, diets, funerary contexts, and rock art rites.

These indicators establish connections between the oasis cemeteries of Pica, the intermediary camps of Pintados, Soronal and the coastal cemeteries of Patillos and Bajo Molle. We conclude that a segment of the Pica oasis population intensified their use of interfluvial sterile passages, where they occupied temporary halts in coexistence with local communities, and transported terrestrial and maritime food surplus. The complexity of these operations suggests the presence of a local socio-political leadership, which was later controlled and expanded during the Inca regime.

Keywords: Caravan circulation - oasis desert coast intermodal mobility - Late Intermediate Period.

Recibido: marzo 2016. Aceptado: diciembre 2016

\section{* Introducción}

Durante el Período Intermedio Tardío en el espacio arreico del norte de Chile se han definido a través de análisis unidireccionales diversas evidencias que han esclarecido la circulación caravanera interpisos ecológicos, integrándose más recientemente los primeros aportes interdisciplinarios (Núñez 1976, 1985; Berenguer 1994; Briones et al. 2005; Cases et al. 2008; Clarkson y Briones 2001; Pimentel 2009, 2013; Pimentel et al. 2011; Petruzzelli et al. 2012; Torres Rouff et al. 2012b; Santana-Sagredo et al. 2015). Desde una perspectiva microespacial se espera contribuir con esta orientación, incorporando diversas fuentes: contextos funerarios, viales, ocupacionales, bioantropológicos, isotópicos y geosimbólicos, para la reconstitución del circuito caravanero entre el oasis de Pica (69 $19^{\prime} 19.72^{\prime \prime} \mathrm{W} / 20^{\circ} 28^{\prime} 36.70^{\prime \prime} \mathrm{S} / 1300 \mathrm{msnm}$ ), dependiente de vertientes, y el litoral arreico aledaño, que cubría unos $118 \mathrm{~km}$ a través del ambiente más desértico del desierto de Atacama. Para establecer vínculos comparativos se han incluido los contextos funerarios sincrónicos del cementerio Pica-8 (Núñez Ms.), con aquellos de Bajo Molle y Patillos, cercanos a la latitud del oasis en el litoral al sur de Iquique, excavados hace siete décadas, conservados en el Museo Regional de esa ciudad (Ancker Nielsen Ms.). Se han integrado además sitios intermedios correlacionados: campamentos, inhumaciones, rutas, geoglifos para concluir con la movilidad inca, para finalmente proponer la naturaleza de estas interacciones oasis-costa (Figura 1).

\section{* El complejo pica-tarapacá y los circuitos CARAVANEROS}

Durante el Desarrollo Regional Tardío (Intermedio Tardío: ca. 900-1450 DC) las ocupaciones en los Valles Occidentales entre el sur peruano y extremo norte de Chile crearon zonas eficientes de desembocaduras con una

\footnotetext{
1 Instituto de Arqueología - Antropología y Museo (IAAM) de la Universidad Católica del Norte, calle Gustavo Le Paige 380, CP 141000o San Pedro de Atacama, CHILE. Email: lautaro.nunez@hotmail.com

2 Museo Arqueológico de la Municipalidad de Pica, Plaza de Armas 20, CP 1170000 Pica, Región de Tarapacá, CHILE. Email: geoglifo2@gmail.com
} 


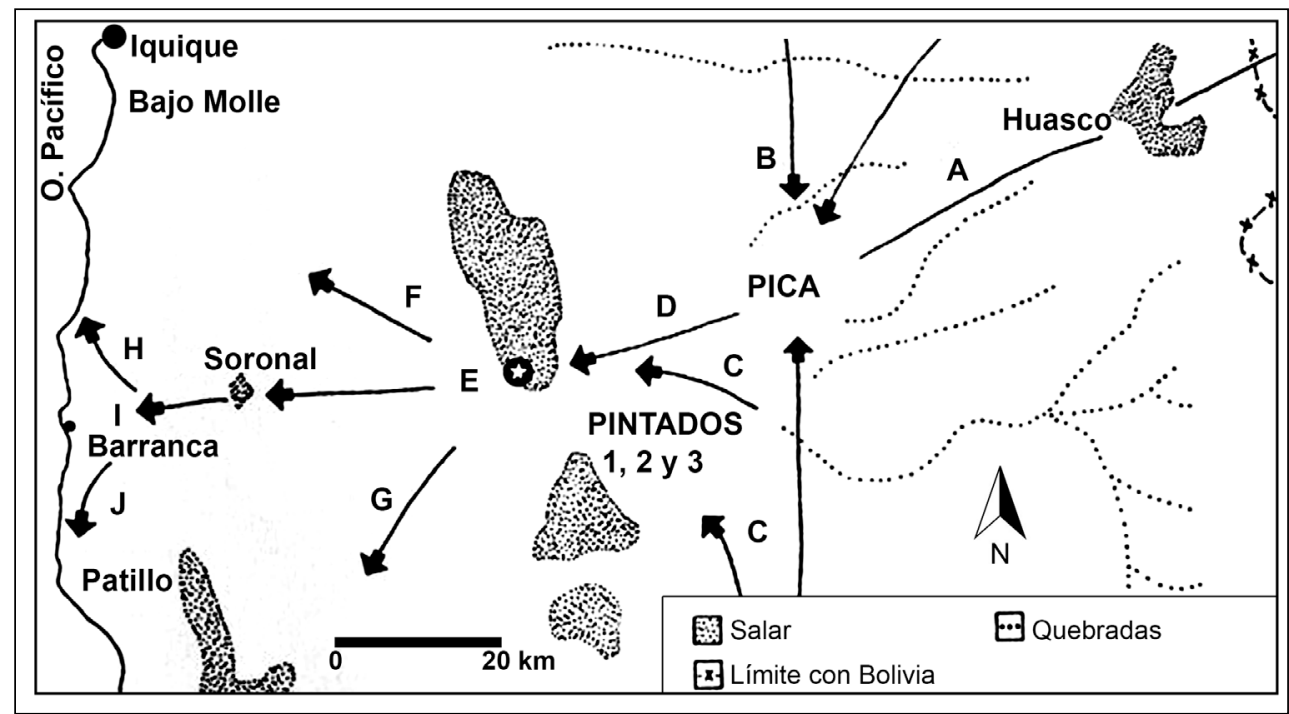

Figura 1. Ubicación del circuito caravanero entre el oasis de Pica con la costa del altiplano. A: Rutas entre Pica - Llica (altiplano de Bolivia). B: Rutas entre Pica y el valle de Tarapacá. C: Rutas entre Pica - quebradas intermedias y Quillagua. D: Rutas entre Pica - salar de Pintados - Soronal - Alto Barranco (costa). E: Rutas hacia la costa desde Pintados. F: Rutas a la costa sur de Iquique (Bajo Molle). G: Rutas a la costa entre Pabellón de Pica y la boca del Loa. H: Rutas entre Soronal y la costa y rutas entre Soronal y la costa de Alto Barranco. J: Rutas entre Soronal - Alto Barranco y Patillo.

intensa concentración, combinación y movimientos de gentes en torno a recursos aeromarítimos. Sin embargo, en los oasis y valles endorreicos tarapaqueños, separados del litoral, ubicados en parches agrarios, los asentamientos segmentados y sus cementerios asociados crearon un mosaico demográfico desagregado y sujeto a un liderazgo con fuerte integración sociopolítica al interior del Complejo Pica-Tarapacá, acotado entre los valles de Camiña y Loa. En estos hábitats piemontanos se han examinado desde sus cementerios, arte rupestre, asentamientos, vestimentas y contenedores, atributos diferenciados con respecto a las comunidades vecinas (Núñez 1966, 1985; Agüero 2015; Uribe 2006 y otros). Los oasis limítrofes de Pica, Matilla y el Valle conforman un espacio representativo del Complejo Pica-Tarapacá, emplazado precisamente en un punto medial entre los Andes y el litoral.

Se ha verificado que en el asentamiento subyacente preinca situado en Tarapacá Viejo y sus alrededores se situaba la élite local y sus comunidades, desde donde dependían las autoridades piqueñas, espacio que fuera reocupado por la administración y labores incas y luego españolas (P. Núñez 1984; Núñez 1979; Urbina 2007). De hecho, dos grandes cementerios Pica-Tarapacá rodean las colinas adyacentes de Tarapacá Viejo. Esto significa que este espacio jerarquizado con arquitectura, cementerios y arte rupestre constituyó el principal centro sociopolítico preinca e inca de las tierras bajas. De acuerdo a la documentación arqueológica e histórica del siglo XVI, las principales cabeceras políticas, asentamientos y cementerios del Complejo Pica-Tarapacá y sus identidades compartidas (p.e. artesanías) se situaban principalmente en el valle bajo de Tarapacá en directa conexión y alianza con el vecino oasis de Pica (Núñez 1992).

El Complejo Pica-Tarapacá comprometido con prácticas caravaneras se determinó inicialmente incluyendo los contextos del cementerio Pica-8, vinculado con asentamientos agrarios dependientes de vertientes del valle de Quisma (Núñez 1966). Por otra parte, las distancias discretas de los recursos complementarios de la laguna alto andina del Huasco, bosques de freatofitos (Pampa del Tamarugal) y del Pacífico estimularon desde esta posición medial una activa movilidad interpisos. Al no constituir un valle alongado como un pasaje natural al mar, se debieron crear tempranamente pasadizos culturales de interacción a través de una red de rutas caravaneras. Este territorio así concebido resolvió el enclaustramiento, integrando a su espacio físico y sociopolítico aquellos lugares con recursos esenciales que incluyeron ciertos enclaves costeros. 
Se trata de valorar la información derivada de registros funerarios (Bindford 1971), para los efectos de identificar los recursos trasladados al litoral en el intento de identificar los componentes locales y foráneos entre las ofrendas de los cementerios piqueños vinculados en esta oportunidad con un espacio acotado entre Pica y el litoral cercano (Moragas 1995; Núñez y Moragas 1976). En este espacio de interregno entre las sociedades ariqueñas y atacameñas las redes transdesérticas crearon las condiciones para un modo particular de articulación agromarítima sin cursos fluviales junto al mar. Para contextualizar estas interacciones es necesario conocer los marcadores de Pica-8, sujetos a traslados. La base agraria se centró en la producción excedentaria de maíz (Zea mays) inherente a las tierras cálidas (incluye "polulos" o "reventados" y tostados), desgranado o en marlos, como cultivo dominante. Se suman: zapallo (Cucurbita maxima), calabaza (Cucurbita), poroto (Phaseolus vulgaris), recolección de chañar (Geoffroea decorticans), jíquima (Pachyrhizus tuberosus), pacay (Inga feuillei), algarrobo (Prosopis chilensis), molle (Schinus molle), tamarugo (Prosopis tamarugo), algodón (Gossypium) y fibras vegetales (Cortaderia sp.). Aunque el ají (Capsicum annuum) está presente con baja representación, su crecimiento fue óptimo, no así las papas (Solanum tuberosum), quinua (Chenopodium quinoa) y el "chuño" (papa deshidratada), traficados selectivamente desde tierras más altas.

Se acepta que en las labores agrícolas locales o para el traslado de cargas menores a nivel doméstico se popularizaron los capachos de tela y fibra vegetal suspendidos desde la frente. Es un ingenio común de uso personal tanto en los valles como en el litoral. Del total de las inhumaciones en Pica-8 se han controlado 24 capachos completos presentes en todas las secciones. Con respecto a la fauna se han documentado los siguientes especímenes: Llama (Lama sp.), hurón (Mustela putorius furo), perros (Canis lupus familiaris), zorro/carcaj (Vulpes vulpes), cuyes (Cavia porcellus), paloma cuculí (Zenaida meloda), tortolita quiguagua (Columbina cruziana), además de quirquinchos (Chaetophractus nationi), guacamayos (Ara spp.), loros (Psittacidae) y parinas (Phoenicoparrus andinus), derivados los últimos del tráfico de larga distancia vía tierras altas, que en varios contextos costeros se han introducido también como bienes de privilegio. Mientras que en recientes campamentos expuestos en Quisma se han reconocido descartes de frecuentes mariscos consumidos in situ (Figura 2a-b).

De los relatos locales etnográficos se sabe que fue posible la crianza reducida de llamas en cautiverio para consumo y uso caravanero, adaptadas a las altas temperaturas en los tiempos prolongados de las transacciones locales (tambo del Resbaladero en el oasis de Pica). Han descendido al litoral sin problemas mayores durante los tiempos de descarga y carga, con forraje trasladado, procediendo a su retorno sin efectos secundarios de acuerdo a la experimentación lograda en la ruta Llica-Pica-Costa de Caramucho (Gedda 2001). Con la acumulación de lanas locales y de rebaños en laguna del Huasco hubo suficiente materia prima para una variada y alta producción de piezas tejidas que se trasladaron y/o manufacturaron en el litoral. Se han sumado en Pica-8 unas 643 piezas

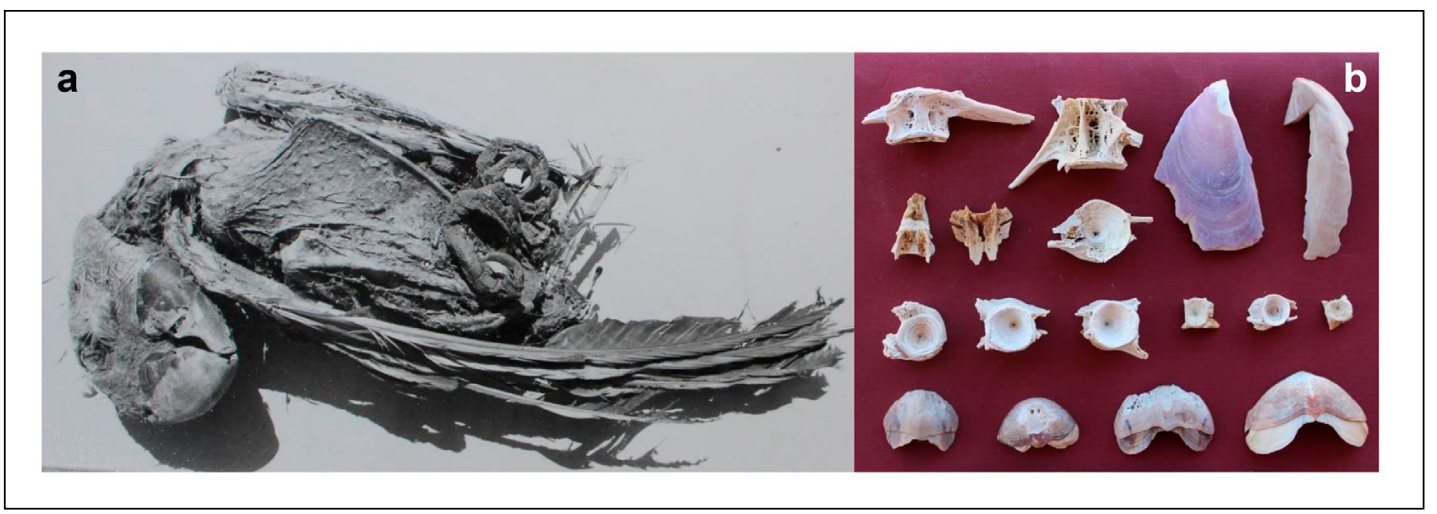

Figura 2. A: Guacamayo registrado en el cementerio Pica-8. B: Restos de pescados y moluscos observados en la superficie de un campamento localizado en el área de vertientes del valle de Quisma. 


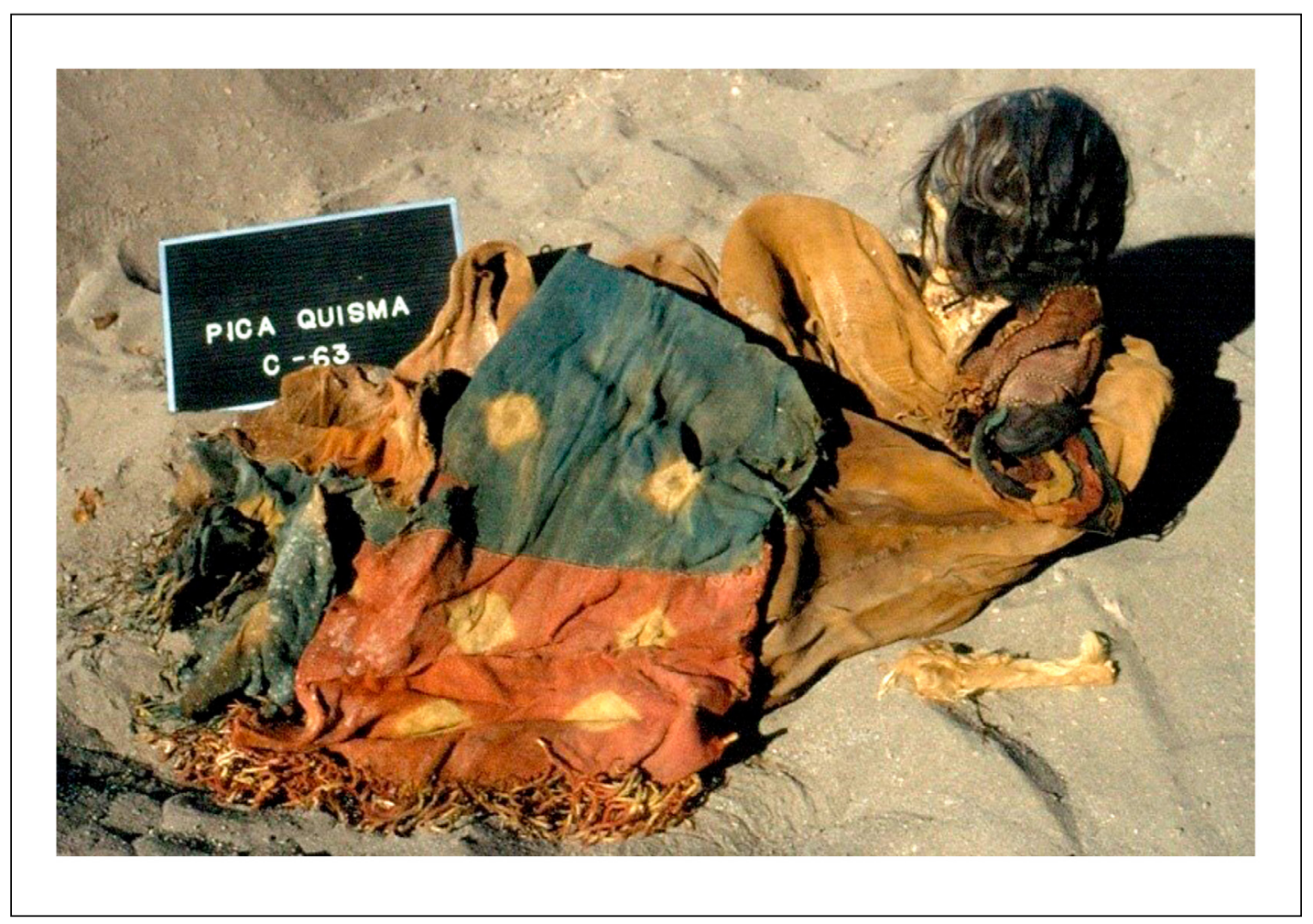

Figura 3. Rescate de un cuerpo proveniente del cementerio Pica-Quisma, asociado a una típica túnica teñida de azul y rojo con amarres y flecos, representativa de las jerarquías locales (Foto gentileza de C. Moragas).

elaboradas a telar que incluyen: camisones, bolsas, fajas, cintillos, paños para cargar y vestimentas, entre otros, demostrándose un potencial artesanal singular (Núñez $\mathrm{Ms).} \mathrm{Al} \mathrm{respecto,} \mathrm{se} \mathrm{han} \mathrm{valorado} \mathrm{como} \mathrm{indicadores} \mathrm{de}$ identidad de la élite Pica-Tarapacá aquellos camisones o túnicas Pica Teñidos con Amarres (Agüero 2015), que representan mensajes simbólicos circulados en la comarca tarapaqueña con el típico fondo teñido de azul y rojo con los adornos de color natural logrado por las ataduras, adornados con flecos (Zlatar 1984; Núñez Ms.). Se rescató otro del cementerio Pica-Quisma (Pica-23), esta vez separado en cuatro fondos teñidos y alternados rojo-azul, incluidos los flecos, asociado a un personaje que debió ser parte de un asentamiento cercano al borde norte de la vertiente de Chintaguay en el valle de Quisma (Moragas 2015 Ms.) (Figura 3). Se repite un registro homólogo en el contexto de un personaje principal que se denominó "Señor de Pica", excavado por Ancker Nielsen en la costa de Bajo Molle, provisto de un efectivo casco de cuero de lobo con plumas de parina, que repite el mismo recorte elevado sobre la vista de los tocados
Cubrecabezas Pica Polícromo, correspondiente a uno de los objetos más jerárquicos del cementerio Pica-8 (Figuras 4, 5 y 6a-b). Otro camisón del mismo patrón se ha registrado en contextos también tardíos en Quillagua y en el cementerio de Chacance, donde se aprecia con un fondo azul y diseños típicos claros no teñidos (Cases y Agüero 2004). Esta circulación de camisones propios de las élites de Pica, a través de los movimientos caravaneros, se interpreta como señal de alianzas mutualísticas, visualizadas por personajes que conducían y organizaban estas operaciones. Es decir, en cada uno de los nodos o asentamientos-ejes incluidos en el tráfico regional había linajes o contrapartes receptoras que acogían la simbología de las cabeceras Pica-Tarapacá. Este indicador textil es importante por su ausencia en este Período Intermedio Tardío en los valles de Arica y San Pedro de Atacama, que remite a ritos de encuentros entre autoridades, donde el camisón o túnica era la pieza de mayor representación del poder, tal como lo captaron los primeros encomenderos precisamente en Pica (Barriga 1955 [1558]. Con la familia cerámica Café Monocroma Alisada también se constata 


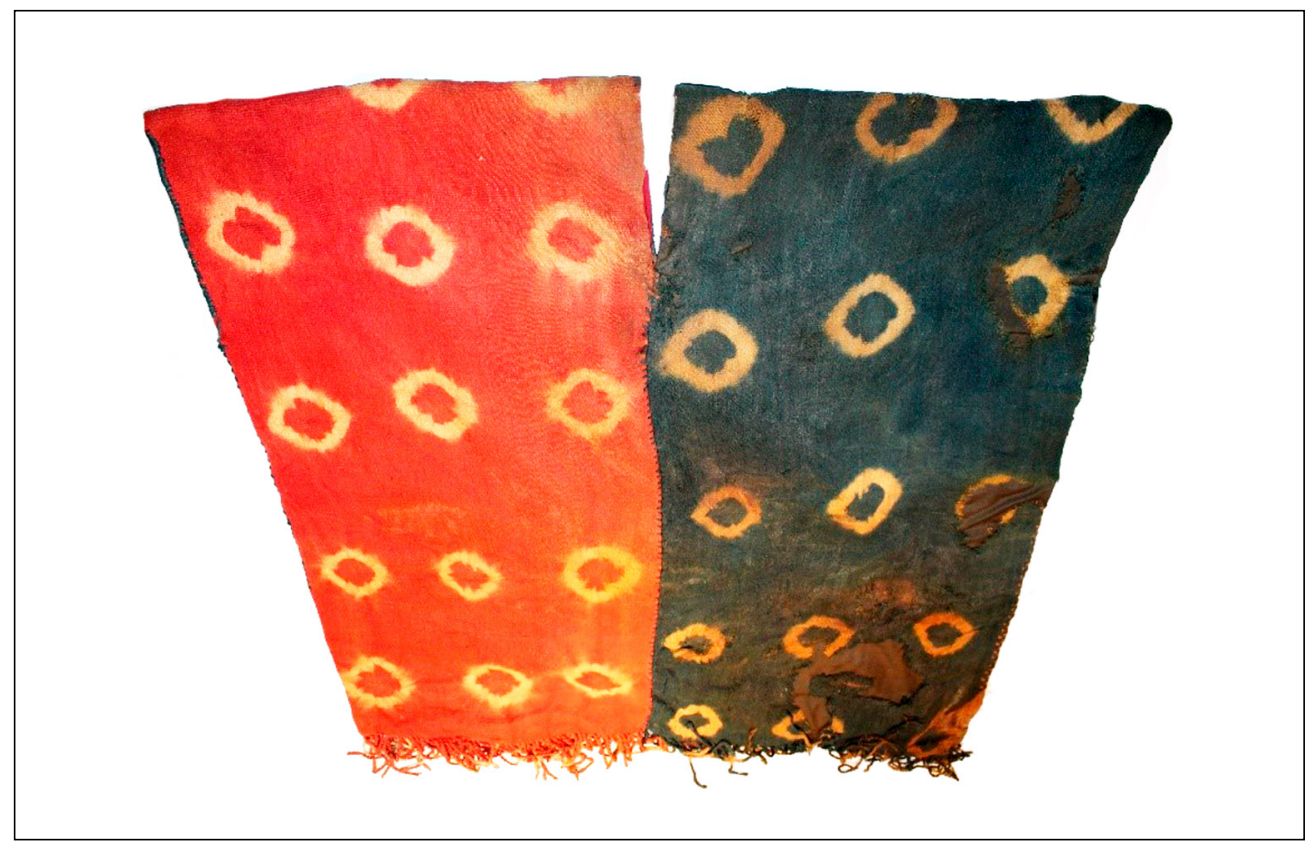

Figura 4. Túnica teñida de azul y rojo con amarres y flecos, excavada por Ancker Nielsen en el cementerio de Bajo Molle al sur de Iquique, derivada de la circulación del tráfico caravanero desde Pica (Museo Regional de Iquique).

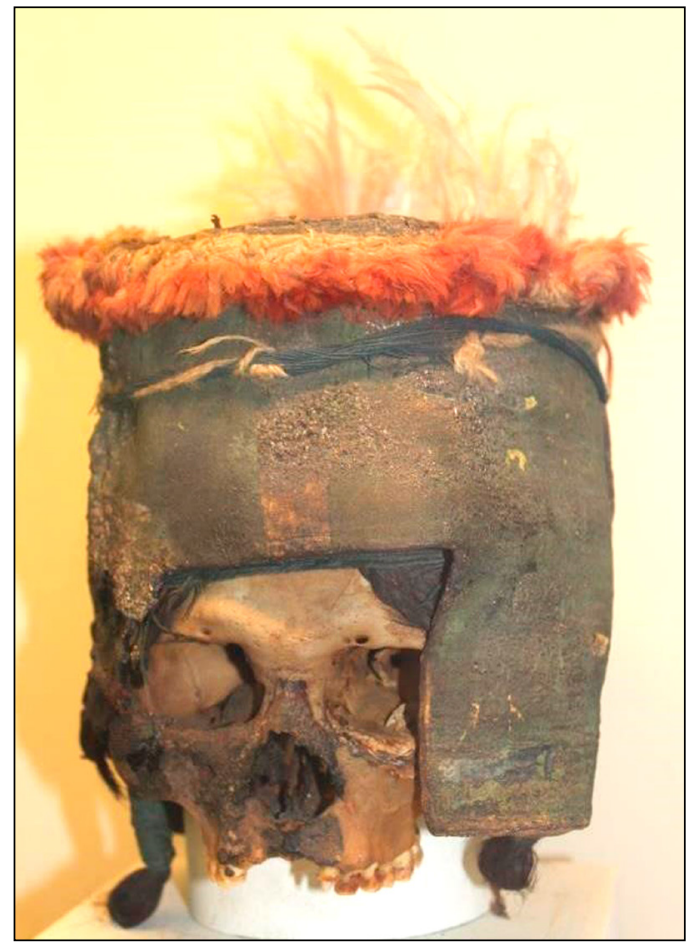

Figura 5. Cuerpo excavado por Ancker Nielsen en el cementerio de Bajo Molle en el sur de Iquique, asociado a la túnica de azul y rojo teñida con amarres. El cráneo presenta in situ un casco de cuero de lobo adornado con plumas de parina, provenientes de los lagos fronterizos (Museo Regional de Iquique). 


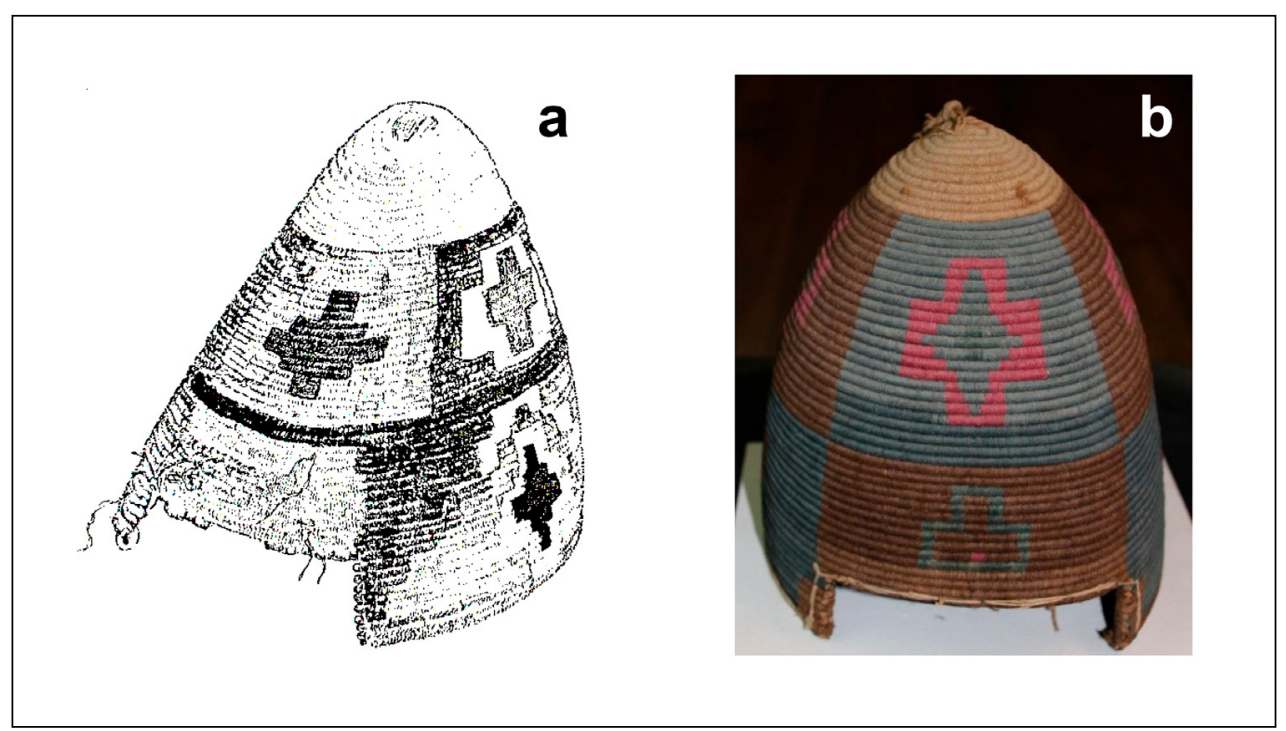

Figura 6. Tocados Pica polícromo. A: Ejemplar procedente del cementerio Pica-8 con el motivo caravanero rombo escalerado. B: Espécimen similar rescatado en la costa del sur de Iquique, derivado del circuito de interacción Pica-costa (Museo Regional de Iquique).

una distribución similar con roles más domésticos a través de las redes de circulación, junto a otros productos tan frecuentes como el maíz.

A partir de las comparaciones entre ofrendas funerarias sincrónicas se advierten relaciones consistentes entre la textilería de Bajo Molle, Patillos (Ancker Nielsen Ms.) y Pica-8 (Núñez Ms.), a través de una alta frecuencia de registros en el litoral referido: bolsas de diversos tamaños, la mayoría con diseños simbólicos, sumadas a talegas y costales grandes con listados paralelos del patrón caravanero. Éstas fueron trasladadas y elaboradas en la costa a juzgar por la presencia en estos cementerios de útiles de coser y tejer. También se repiten objetos piqueños tales como: sombreros, fajas, hondas y camisones con iguales diseños, mantas gruesas "felpudas", capachos, peinados con embarrilados de lanas teñidas y adornos tobilleros.

Los bienes sujetos a traslados no siempre fueron de uso doméstico y subsistencial, sino que tuvieron también roles simbólicos y ritualísticos como las hojas de coca, fauna, semillas y plumas exóticas, que respondían a significados compartidos. En este sentido el déficit de piezas metálicas en los nodos de este circuito se suma a la ausencia de lingotes y lingoteras rectangulares en Pica-8, salvo una circular (Pi-8/SB/T-16). Del total de las secciones de
Pica-8 con un total de 243 individuos documentados se han registrado solo una pulsera y plaquita de cobre en la sección D y J, respectivamente. El déficit de prácticas mineras se debería a la ausencia de afloramientos cercanos, tal como se advierte con la única lingotera registrada en el campamento caravanero de Pintados que unía Pica con la costa. Esto significa que debían acceder a recursos alejados, trasladando los equipos para fundir metales fuera del oasis. Otro antecedente importante se advirtió en un enterramiento de Pica-8, cuyo cráneo exponía en la zona frontal el negativo de una placa de cobre que lo tiñó de verde por el tiempo en que permaneció in situ. La ausencia de la placa y el carácter intacto del cuerpo y de las ofrendas sofisticadas sugiere que fue sustraída durante el tiempo cercano a la inhumación a raíz del valor que adquirieron estas piezas de privilegio para sus propios contemporáneos. Tal escasez de metales en piezas de estatus también se representa en la costa referida, donde son relativamente frecuentes solo los anzuelos de cobre.

El movimiento de bienes hacia el litoral cercano se complementó además con el arribo al oasis de bienes laterales e interiores constatados en Pica-8, como la alfarería de Arica, del altiplano meridional (Huruquilla) y del río Loa (Dupont), incorporados a una matriz cultural homogénea con estilos artesanales y simbólicos identitarios 
locales. Por otra parte, habrían interactuado con asentamientos vinculados con enterramientos en cistas y chullpas en Laymisiña (Camiña) y Nama, conectados con el altiplano de Isluga. Efectivamente, con los poblados tardíos de Camiña, Nama, Chusmiza y Jamajuga, también se mantenían vínculos a su vez complementarios (Urbina y Adán 2006, Núñez 1992). En estos desplazamientos se ha observado el frecuente registro fuera del oasis, como sucedió en el oasis de Quillagua, de camisones trapezoidales y talegas de carga comunes en Pica-8 (Núñez 1985; Agüero 2015; Cases 2003, 2004).

Sin embargo, es conveniente explicar cuál fue la dimensión de estos contactos extralocales para evaluar el grado de eventuales intrusiones demográficas foráneas. Los densos cementerios de Pica de este período (Pica 1, 2, 3, $7,8,23,42,44,46)$, considerando sus límites periféricos, se calculan aproximadamente en unos $53.310 \mathrm{~m} 2$, mientras que la notable expansión aldeana tardía, como Camiña y Tarapacá, da cuenta en conjunto de densas poblaciones durante el Intermedio Tardío que usan cerámica Pica-Tarapacá, junto a interacciones con agrupaciones alteñas que se representan por la cerámica Chilpe y otras variantes negro sobre rojo e intrusiones de tiestos polícromos de Arica. Se sugiere, entonces, que ciertas agrupaciones de valles bajos de más al norte y otros de más altura habrían convivido insertas o en tránsito al interior de la mayoría étnica local Pica-Tarapacá.

La población tarapaqueña, más que representar una difusa multietnicidad a raíz de sus conexiones de movilidad con la costa arreica, valles aledaños, sierra y altiplano aledaño, pareciera que había consolidado en los últimos siglos una sociedad monoétnica, derivada de comunidades formativas locales con ciertos componentes intrusivos multiétnicos. A lo largo del trayecto costa-altiplano, de no más de $250 \mathrm{~km}$, se localizaba una alta producción complementaria y diversa entre sí que estimuló el movimiento caravanero y los contactos interétnicos en un perfil que incluía identidades entrecruzadas costeras, de oasis, valles serranos y altiplano, al interior de las densas comunidades locales Pica-Tarapacá.

\section{* Prácticas Caravaneras y armonía social}

Para sostener una red vial transectual de esta naturaleza, se requiere de arreglos políticos interétnicos en términos de lograr ciertos grados de equilibrio social. No obstante, la imagen de múltiples obras defensivas en altura, armas ad hoc y altas tasas de impactos letales detectados desde la bioantropología han señalado que las guerras sensu lato fueron dominantes al parecer a lo largo de los Andes (Arkush y Tung 2013; Arkush y Stanish 2005). Por otra parte, la presencia de un cordón de pukaras en las tierras altas del Noroeste Argentino ha sustentado tiempos de hostilidad y violencia interpersonal (Nielsen 2015; Gheggi y Seldes 2012), en tanto que en los oasis de Atacama se han verificado severos eventos de conflictos también durante el Intermedio Tardío (Torres-Rouff y Costa 2006; Lessa 2004). ¿Cuál fue el tiempo real de estos conflictos? ¿O es que no existieron intervalos como la llamada Pax Aymara para reanudar los ideales de interacción propiamente andinos? (Murra 1972; Núñez y Dillehay 1979). ¿Cuántas entradas de conquista y de aparente devastación no eran sino ataques sorpresivos para lograr complementariedad de recursos a través del botín? Sobre todo, en aquellos espacios como los meridionales donde las comunidades étnicas pre estatales, como los Señoríos, no eran tan expansivas en comparación con los Andes centrales.

Se sabe que las comunidades exclusivamente pastoralistas por su propia dinámica de sus modos de vida basados en la crianza y caravaneo se ausentaban de estos conflictos (Nielsen 2015). Así, los Lípez altiplánicos ganaderos y caravaneros sin nexos fijos a prácticas agrarias fueron observados al tiempo del contacto histórico como "comerciantes" que logran "contratos" y "rescates", que no son de paz ni de guerra y que trafican precisamente junto a caravaneros tarapaqueños (Lozano Machuca 1885 [1581], Martínez 1986). De hecho, se acepta que los Chichas interactuaron con la vertiente occidental de la puna y establecieron alianzas con las comunidades transcordilleranas durante el temprano siglo XVI, particularmente con los Atacamas (Angelo y Capriles 2000; Bibar 1966 [1558]).

En estas sociedades tarapaqueñas segmentadas, las necesidades de fusión e integración fueron parte de su propio ideario de pervivencia. La consolidación de las élites implicó la búsqueda de alianzas para resolver las disputas por las vías pacíficas sin sobredimensionar los límites fronterizos, sino que, al revés, dejando los confines vallesteros, serranos-altiplánicos bajo una deliberada 
ambigüedad interdigitada. Esto explicaría que en los ambientes serranos tarapaqueños limítrofes existen varias elevaciones con estructuras defensivas sin presentar la escala ni la complejidad de aquellos pukaras circumpuneños. Se han situado en la quebrada de Tana, Siñaguache (Chiapa), Chusmiza, Mocha (Tarapacá), Jamajuga (cerro Gentilar) y Nama, entre otros (Sanhueza y Olmos 1981; Núñez 1985; Adán et al. 2007). Sin embargo, bajo la cota de los 2500 a $2000 \mathrm{~m}$ no se han identificado sitios defensivos en el entorno de los centros agrarios aldeanos donde se concentran las poblaciones y el poder de las tierras bajas, como es el caso de los espacios fértiles de Tarapacá y Pica.

En este sentido el Pukara Mocha-1, situado a los 2000 msnm, en el valle de Tarapacá, ejemplifica como pudieron plantearse las relaciones de coexistencia de las comunidades Pica-Tarapacá con agrupaciones cercanas de mayor altura, dispuestas en aterrazamientos escalerados (Moragas 1991). Las prácticas de molienda de maíz se asocian con cerámica mayoritaria del Complejo Pica-Tarapacá representada por el cántaro globular alisado de base cónica sin asas, junto a restos de conchas del Pacífico: almeja (Protothaca thaca), ostión (Pecten sp.) y posibles adornos de oliva (Oliva peruviana Lamk) (Moragas op. cit.). La segunda frecuencia les corresponde a los pucos altiplánicos Chilpe con diseños negro sobre enlucido rojizo, con diseños geométricos en los bordes. Estos contenedores responderían a grupos que convivieron con la ocupación Pica-Tarapacá, sin relaciones de conflictos, junto a escasos tiestos con motivos negro sobre blanco, también de posible filiación altiplánica Huruquilla (Moragas op. cit.; Núñez 1985). La cerámica Pica-Tarapacá junto a restos de fogón, pescados y marlos de maíz fue datada a los 720 años AP (1230 DC), a comienzo de ambas ocupaciones de cumbre (Moragas op. cit.).

Estas evidencias se han interpretado como eventos de interacción entre oasis y valles conectados con el litoral y el altiplano, con ocupaciones Pica-Tarapacá junto a alteños transitorios sin prácticas de inhumación en chullpas o cistas que indiquen estabilidad territorial. La explotación de maizales expandidos a lo largo del valle de Tarapacá hasta Mocha se explicaría con acciones pactadas de complementariedad con agrupaciones de las tierras altas y sus cargas de intercambio. Al pie del pukara se sitúa el cementerio Mocha-2 con infantes inhumados al interior de cántaros Pica-Tarapacá, donde se destacan aquellos representativos de bases cónicas sin asas junto a los Pica-Chiza Modelados y otros componentes sincrónicos asociados. La ausencia de cerámica Chilpe en los enterramientos ha indicado correctamente que el cementerio responde a una ocupación Pica-Tarapacá y en consecuencia la presencia Chilpe en los espacios domésticos del asentamiento probaría el carácter armónico de ambas agrupaciones con actividades compartidas (Moragas op. cit.).

Por otra parte, en el cementerio solo se observó un adulto masculino afectado por una fractura a nivel de pierna y otra en acromion, vinculadas más bien a un accidente que a un conflicto interpersonal (Standen y Sanhueza 1984). De modo que con los datos en su conjunto no se han identificado evidencias para plantear aquí una propuesta de violencia con solo el argumento defensivo (Moragas 1991), como tampoco los hay para involucrar a las comunidades enterradas en Pica- 8 con la propuesta de supuestos daños derivados de competencias ambiguas intra y extralocales (Uribe 2006: 107).

En cuanto a que en los asentamientos bajos, como en Pica y Tarapacá, la producción de maíz fue altamente productiva: ¿qué interés habría en ocupar un espacio maicero en Mocha? Con este argumento sería más plausible la tesis del arribo de agrupaciones alteñas que en sus espacios originarios no producían maíz. El interés por Mocha sería por una parte el afloramiento de crisocola y malaquita. Entre las comunidades Pica-Tarapacá son escasos estos recursos, tanto para lapidaria y fundición de metales, de modo que estos afloramientos pudieron transformar este locus en un espacio de atracción biétnica. Al parecer, durante los tiempos de cosecha los Pica-Tarapacá junto con los afuerinos alteños estaban abocados a la preparación de harina de maíz (abundancia de manos y metates) y productos marinos, transformados en cargas caravaneras hacia las tierras altas junto a la recepción de bienes y productos de altura. Este nodo de interacción estaba particularmente ritualizado en torno a rutas asociadas a geoglifos del estilo tarapaqueño: rombos escalerados, quizás los más altos de todos, cruz de Malta, círculo concéntrico, individuo con báculo y caravana además de varios círculos. Se sugiere que este espacio se había constituido en un punto de encuentro caravanero interétnico, orientado a prácticas de intercambio y preparación de caravanas. De ser así, Mocha se habría transformado en un 
nodo atractivo compartido, sin conflictos, por una causa u otra y ameritaba ser defendido ante posibles asaltos en tiempos de explotación maicera y minera.

Sería ingenuo aceptar un Intermedio Tardío en los valles bajos apegados al Pacífico sin roces intersociales. No obstante, el tráfico giratorio y las operaciones de colonización e intercambio señalan más bien ausencia de conflictos cercanos a "guerras" e indicarían más tiempos dedicados a la búsqueda de alianzas y tratos armónicos con evidentes ventajas mutualísticas (Murra 1972; Núñez y Dillehay 1979; Briones et al. 2005; Pimentel 2009). Que no se entienda que las comunidades Pica-Tarapacá estaban exentas de conflictos (Núñez 1985; Odone 1995), pero no entramados en guerras a escala de agresiones de relativa larga duración.

Esta ausencia de supuestas "guerras" se documenta mejor con el examen de 96 cuerpos precisamente del cementerio Pica-8, donde no se evidenciaron excesivos indicios de violencia, salvo en un individuo flechado excepcionalmente. El resto se atribuye a violencia ritual organizada para atenuar tensiones internas y lograr un mayor equilibrio social. De hecho, las lesiones traumáticas alcanzan solo a un $14,58 \%$, vinculadas con prácticas ocupacionales, accidentes y caídas fortuitas. Es notable la ausencia de traumas craneanos en adultos, cuyas consecuencias letales alcanzan solo un 5,2\%. Representación bajísima en relación a los eventos de conflictos severos identificados en San Pedro de Atacama, que alcanzan un $35 \%$, mientras que las mujeres en Pica presentan únicamente daños derivados del género de naturaleza doméstica (Pacheco 2010; Pacheco y Retamal 2014, 2015).

\section{* Interacción entre el cementerio pica-8 y Los Costeros De bajo MOlle y PATIllos}

A pesar de las múltiples evidencias de interacción con la costa, llama la atención la escasa presencia de marcadores del litoral en los contextos funerarios de Pica-8: restos mínimos de pescados, caracoles y cuentas de conchas (Zlatar 1984; Núñez Ms). Tal situación aparentemente contradice la notable presencia de componentes de Pica-8 en los cementerios costeros y los depósitos en rutas. Por lo anterior, se sugiere que las cargas de alimentos costeros por su carácter excepcional, en términos de consumo, no fueron incorporadas a las ofrendas funerarias en Pica-
8 a diferencia del abundante maíz local. De modo que en lo relativo a ofrendas comparadas se pondrá énfasis en los registros similares a Pica-8, recurrentes en los cementerios costeros de Bajo Molle y Patillos, con información confiable rescatada décadas atrás desde sitios que hoy se advierten desaparecidos dada su destrucción total (Ancker Nielsen Ms.).

\section{El cementerio de Bajo Molle}

Se constataron ofrendas similares a Pica- 8 con materiales vegetales: cestería en espiral, capachos de carga, zampoñas de cañas, instrumentos de espinas de cactus, maíz, calabazas, algodón, ají, porotos y harinas. Otro tanto pasa con los objetos de madera: peines, flechas, tapones cilíndricos, husos y torteras de hilar, varillas de telar, cencerros y ganchos de atalaje. Sin embargo, con las maderas provenientes del interior se elaboraron principalmente instrumentos de uso costero: cabeceras de arpones, remos, coplas de remos, portaarpones, balsas de tres cuerpos y mangos de cuchillos. Se destaca también el uso del portacarga escalerado, suspendido desde la frente, usado en el tráfico entre el litoral y los oasis, también observado en los cementerios Soronal-3, Pica-7 y Caleta Huelén-12. Los artefactos de hueso se limitan a agujas, vichuñas (apretadores de tramas en telares) y tubos, no obstante, la mayor frecuencia de esta materialidad se centró en actividades costeras: arpones, chuzos de mariscar y barbas de arpones. La cerámica representa en su conjunto al Complejo Pica-Tarapacá con contenedores Pica Cántaros Globulares brochados o estriados de base cónica, Pica-Chiza Modelado antropozoomorfo (Figura 7), platos alisados, ollas asimétricas con un asa, botelliformes, incluyendo piezas foráneas como cántaros San Miguel de Arica, escasos aribaloides tardíos, tiestos miniaturas y algunas inhumaciones de infantes al interior de cántaros fracturados. Los objetos metálicos también son escasos: hoja de hacha, brazalete, cuentas y anillos, aunque son mucho más comunes los anzuelos de cobre que con mayor diversidad recuerdan aquellos del cementerio Pica-7 del contacto inca. En relación a la fauna marina la presencia es obviamente mayoritaria. ${ }^{3}$

3 En el cementerio de Bajo Molle se han observado restos de mariscos, pescados, flotadores y bolsas de agua de vejigas de lobos marinos, cuerdas de lobo para arpones, restos de aves, cuchillos enmangados, fragmentos de balsas de cuero de lobo y un casco de igual materialidad que sigue el formato de aquellos tocados o 


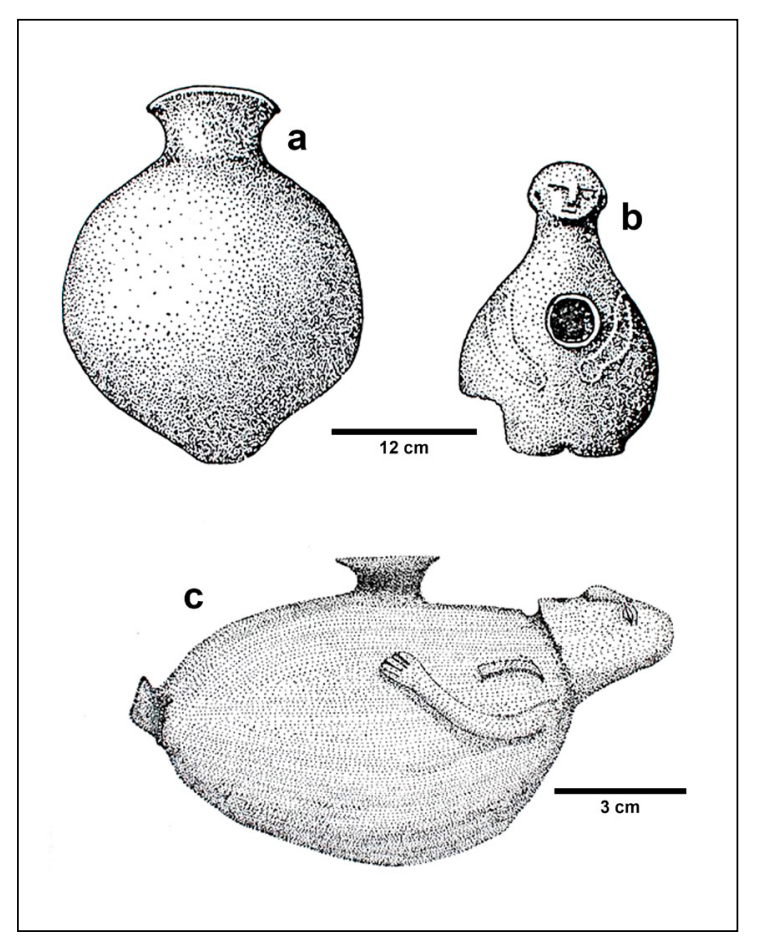

Figura 7. Cerámica representativa del Complejo PicaTarapacá, distribuida a través del circuito caravanero, incluida la costa arreica. A: Cántaro Pica globular estriado de base cónica (cementerio Pica-8). B: Chiza modelado procedente del mismo cementerio. C: Chiza modelado registrado en el cementerio Pica-2.

También se repite en la costa la presencia de plumas de aves no locales, útiles de textilería, sombreros tardíos tipo Fez Polícromos con penachos, escasas cuentas de malaquita, pigmento verde, fardos funerarios con camisones, atados de pelo humano y en ambos espacios comparados la alta frecuencia de ojotas de cuero. Finalmente, en coincidencia con Pica-8, la casi ausencia de pescado seco o salado se explicaría, como en el caso de las carnes secas, por ser bienes apreciados más consumidos que ofrendados.

Cubrecabezas Pica Polícromo, adornado también con penacho de plumas foráneas. En general, en la costa fuera del uso de pieles de zorros para preparar portaflechas como los de Pica- 8 y escasos cuernos de ciervos locales usados como instrumentos, el resto son evidencias aisladas de carácter foráneo, iguales a las de Pica8: plumas de avestruz y de aves tropicales, restos de camélidos, perros y solo un trozo de charqui tan escaso como en los registros de Pica-8 (Ancker Nielsen Ms.).
En suma, las mayores frecuencias de las ofrendas en Bajo Molle (Ancker Nielsen Ms.), provenientes de los oasis de Pica, recaen en las siguientes cantidades: capachos (10), tapones cilíndricos de madera (15), husos y torteras de hilar (11), bolsa polícroma con hojas de coca (1), restos óseos de camélidos (6), tocado de plumas tropicales (3), plumas de avestruz (4), plumas de guacamayo (2), bolsas con maíz (13), maíz (9), tablas transversales de portacarga similares a Pica-7 (3). Se han publicado tres dataciones ${ }^{14} \mathrm{C}$ para diversos contextos de este cementerio que resultan coherentes con aquellas de Pica-8: 1252, 1247 y 1253 años DC (Moragas 1995), de modo que las comparaciones se ajustan en un rango sincrónico coherente.

Particular importancia constituye el hallazgo de Ancker Nielsen, en el año 1939, de un adulto que porta un casco de cuero de lobo, inhumado en Bajo Molle, que simila los tocados Cubrecabezas Pica Polícromo con penacho de plumas foráneas. Es importante su asociación a objetos comunes en Pica-8: talegas con diseños listados, faja polícroma, bolsa polícroma con harina de maíz, costal, paño con cordelillos en sus cuatro extremos para hacer atados, camisones, calabaza, cestería coiled decorada, bolsa aterciopelada con diseños, atado de pelo humano, carcaj de cuero de zorro, flechas, cerámica miniatura, brazalete metálico, tiesto Pica-Chiza Modelado antropomorfo, plato semiglobular y el icónico camisón con teñido azul y adornos de amarre. Fuera de duda, este "Señor de Pica" (Núñez Ms.), datado a los 1258 DC en sincronía con Pica-8 (Moragas 1995), representa a un personaje principal que por su investidura desempeñaría un liderazgo costero vinculado a las jerarquías de Pica. De hecho, su camisón no se repite en el sitio y nada de lo ofrendado se vincula con objetos y materialidades costeras.

Es muy posible que los portadores de los cascos de cuero de lobo representen jerarquías periféricas del Complejo Pica-Tarapacá, en tanto en los oasis fue más representativo el tocado Cubrecabeza Pica Polícromo con el mismo diseño caracterizado por el corte frontal y las aplicaciones de plumas exóticas. La aplicación del cuero de lobo otorgaba una identidad marina inequívoca, dada su recurrencia en Bajo Molle y en el cementerio sincrónico de Chacance, con aplicaciones decorativas de pintura y plumas (Agüero 2015). En este caso también se reitera el camisón Pica Teñido con Amarres, con fondo y flecos azulados, que demostraría la presencia de un personaje vinculado con el liderazgo piqueño en una de las 
fronteras de interacción. En este sentido, estos camisones serían vestimentas de estatus que pudieron ser entregados como donativos o usados para visibilizar alianzas con reconocimiento público por medio de símbolos compartidos, tal como se observó en Pica durante el tiempo de contacto histórico (Murra 1989; Barriga 1955 [1558]).

\section{El cementerio de Patillos}

Se sitúa en una caleta también protegida a unos $10 \mathrm{~km} \mathrm{al}$ sur de las rutas caravaneras que descienden al litoral por las huellas de Alto Caramucho, marcadas con geoglifos con rombos escalerados en un cerrillo visible desde la costa. Obviamente se destacan contextos costeros: chuzos de huesos para mariscar y desconchar, arpones, conchas, restos de lobos marinos, lienzas, pesas, rollos de cuero para arponear, sardinas, arpones de hueso, espinas de pescados y anzuelos de cobre. La presencia de cerámica Pica-Tarapacá se distingue con el tipo Pica Cántaro Globular de base cónica, estriado o alisado, el más reiterado en estos oasis, incluyendo la intrusión de cántaros San Miguel y los Pica-Chiza Modelado, con un diseño de mujer tendida con trenzas (Moragas 1995; Figs. 1 y 3). Otros marcadores similares a Pica- 8 demuestran vínculos directos cuantificados, derivados de la conexión caravanera. ${ }^{4}$ En general los contextos de Patillos son similares a Bajo Molle tanto en textilería como en artefactos de uso costero, incluida la cerámica, con proporciones similares, aunque con algo más de implementos metálicos. Incluso, la recurrencia del casco de cuero, coca y la alta tasa del orden del $40 \%$ de piezas remendadas similan también a los registros de Bajo Molle, interpretadas como arregladas, derivadas de las operaciones de intercambio (Agüero 2015). El uso de escasos implementos de textilería en Patillos se debería a la carencia de materia prima o al uso de

4 Estos marcadores se enumeran en cantidades: capachos y fajas frontales (9), bolsa con hojas de coca (1), husos y torteras de hilar (5), equipo de textilería con vichuña, huso y tortera (1), restos óseos de camélidos (4), atado de charqui de camélido (1), bolsa polícroma con pescado (1), bolsas con maíz (6), maíz (7) y cencerro de madera (1). A diferencia de Bajo Molle es notable la presencia de tabletas de inhalación con diseños de la tradición atacameña, representados por el sacrificador, cóndor y felino, derivados de las conexiones a través del río Loa. Se destaca además la inhumación de un cuerpo que representa un liderazgo costero ataviado con prendas y bienes similares a Pica- 8 , con un casco de cuero de lobo en proceso de elaboración similar a Bajo Molle (Núñez 1969; Moragas 1995). sucedáneos locales como los contenedores de malla que reemplazarían en parte a los contenedores tejidos, incentivándose el uso de piezas reparadas.

Al examinar el contexto específico de una inhumación de este cementerio, se puede captar la combinación de indicadores locales y foráneos. Se trata de la presencia de una tableta de inhalación con incrustaciones de malaquita, dentro de una bolsa listada, con el ícono sacrificador, ataviado de máscara zoomorfa, de aquellas que son comunes en Atacama. Se le asocian las siguientes ofrendas de oasis: bolsa listada polícroma, fragmento de camisón, vellones de lana, colgantes con protúberos de semillas de algodón, bolsa textil con diseños polícromos y perros. Entre los materiales costeros se aprecian: cuchillo de lasca retocada, fragmento de cuero de lobo teñido con pigmento rojo, paño textil con conchas de cholga (Aulacomya atra) y cabecera de arpón de madera.

Es posible otra vez que en Patillo ocurriera lo mismo observado en Bajo Molle, esto es, que también descendían grupos a esta caleta, de modo que en este caso se trata de un hombre que interactúa tanto con los oasis piqueños por los textiles y con el Loa o San Pedro de acuerdo al equipo de inhalar, similar a los usados en el cementerio sincrónico de Chunchurí (Calama) y con ello integraba componentes multiculturales según las fronteras flexibles propias de la dinámica del borde sur del Complejo Pica-Tarapacá. En ambos sitios costeros se muestra una alta diversidad de vestimentas y piezas tejidas con énfasis en el manejo de bolsas de acuerdo a la movilidad de excedentes, con frecuencia comparables en ambos cementerios, tal como ocurre con talegas y costales realizados de una misma manera y diseños compartidos. En el caso de Patillos, los diferentes tipos textiles alcanzan un $44 \%$ de prendas elaboradas bajo los patrones observados en Pica-8, seguidos de piezas loínas, atacameñas y ariqueñas allegadas durante las conexiones caravaneras (Agüero 2015).

La interdependencia entre los oasis piqueños y la costa de Patillo-Bajo Molle es importante si se asume, por ejemplo, que las piezas de telares requerían de la mano de obra piqueña dispuesta en el litoral o del arribo de piezas terminadas con las operaciones caravaneras. De modo que se dependía de lanas traficadas desde la conexión tierras altas-oasis-costa para intensificar la circulación de la 
textilería del Complejo Pica-Tarapacá, que alcanzó hasta los confines de su territorio, bordeando la costa, las quebradas limítrofes hasta el Loa inferior (Cases 2003, 2004; Agüero 2015; Moragas 1995).

\section{* Análisis de dietas del cementerio pica-8}

Los análisis de isótopos estables de carbono-nitrógeno muestreados desde cuerpos al interior de la costa abren nuevas expectativas para la presente discusión, en cuanto señalan que los alimentos marinos eran importantes en los oasis interiores (Pestle et al. 2015; Santana-Sagredo 2011; Torres-Rouff et al. 2012a-b). En Quillagua extensos maizales, algarrobales y maderas, entre otros recursos, constituían espacios complementarios para los costeños, mientras que la producción costera era atractiva para el descenso de los caravaneros del Loa (Pimentel 2009). Esto explica el registro de fallecidos también en rutas peatonales en pampas estériles, asociados a evidencias costeras y de oasis entre la costa y Quillagua sin vinculación a huellas caravaneras (Cases et al. 2008).

En este sentido, los primeros análisis isotópicos aplicados en el cementerio Pica-8 recobran un interés particular en torno a la naturaleza de estos contactos. Se consideraron dos hombres y cuatro mujeres, todos adultos, los que dieron cuenta de un consumo de alimentos marinos con un alto nivel trófico, asociado a la ingesta de maíz (Petruzzelli et al. 2012). Se ha propuesto que estas relaciones existieron y que ciertos individuos de ambos géneros formaron parte de grupos, quizás pequeños, interpretados como colonias costeras encargadas de los intercambios y que luego retornan al oasis (Petruzzelli op. cit.). Estos análisis vienen a confirmar la interacción con la costa a juzgar por un alto consumo de dieta marina y maicera coincidente con los datos de diversas fuentes aquí presentadas, como la abundancia de maíces en los contextos funerarios costeros, en las paskanas intermedias junto a las rutas y en las ofrendas cuantiosas de Pica-8.

Estudios isotópicos más recientes han ampliado este acercamiento costero también desde el cementerio Pica8 , apuntando a un alto consumo de dieta marina y maíces muestreados en 30 individuos provenientes de las secciones excavadas (A, D, G, I), diversificando las variaciones alimentarias (Santana-Sagredo et al. 2015). En la sección I donde el análisis isotópico dio cuenta de un alto consumo de dieta marina en relación al resto de los sectores excavados, se habría enterrado a la mayoría de los retornados del litoral. Un examen del conjunto del sitio señala la identificación de tres grupos dietarios, siendo el primero dominado por el consumo marino y de maíces. En el segundo se incrementó el consumo de maíz con disminución del aporte marino. El tercero se corresponde exclusivamente con recursos terrestres, observándose que un individuo que mantuvo una dieta terrestre hasta su temprana juventud transitó a otra marina y vegetal (maíz), similar al grupo primero, otra señal concreta de traslados entre el oasis y la costa. De la misma manera como otro individuo que muestra un alto consumo de alimentos marinos y menor presencia de maíz, sugiere una menor permanencia en el oasis (Santana-Sagredo et al. op. cit.). Los grupos movilizados descendían o ascendían y sus entierros pudieron ocurrir en cualquiera de los sectores de Pica- 8 o en los cementerios costeros comparados. Pero lo relevante es que existieron fuerzas de tareas de estos oasis que vivieron largas temporadas en el litoral aledaño y se enterraron en Pica-8. De modo que los análisis isotópicos no solo confirman estos traslados, sino que además aprobarían que existieran segmentos especializados en ocupar la costa, donde los enclaves de Patillo y Bajo Molle podrían ser los espacios de interacción más indicados por su cronología y contextos comparados.

\section{* LA CONEXIÓN PICA-COSTA: RUTAS, CAMPAMENTOS Y GEOSÍMBOLOS}

\section{Las rutas de interacción}

Para cronologizar estos eventos de movilidad es necesario revisar las dataciones ${ }^{14} \mathrm{C}$ disponibles. Una aproximación cronológica de la conexión Pica-costa aledaña considera 15 dataciones de los cementerios de Pica-8, Bajo Molle-1 y las obtenidas en las rutas de interacción (ver Anexo). Se acepta que hubo una primera exploración arcaica-formativa temprana, detectada en una inhumación datada cerca de una paskana caravanera en cerro Monos a los 1212 AC. Corresponde a un caminante costero que ascendía probablemente para obtener los recursos abiertos de pampa del Tamarugal (Briones et al. 2005). El clímax de los eventos con llamas cargueras sucedió entre los 1021 y 1407 años DC. Las dos fechas más tempranas se sitúan en sincronía con Pica-8: 887 y 982 años DC, y con aquella de Bajo Molle de los 898 años DC. Las más 


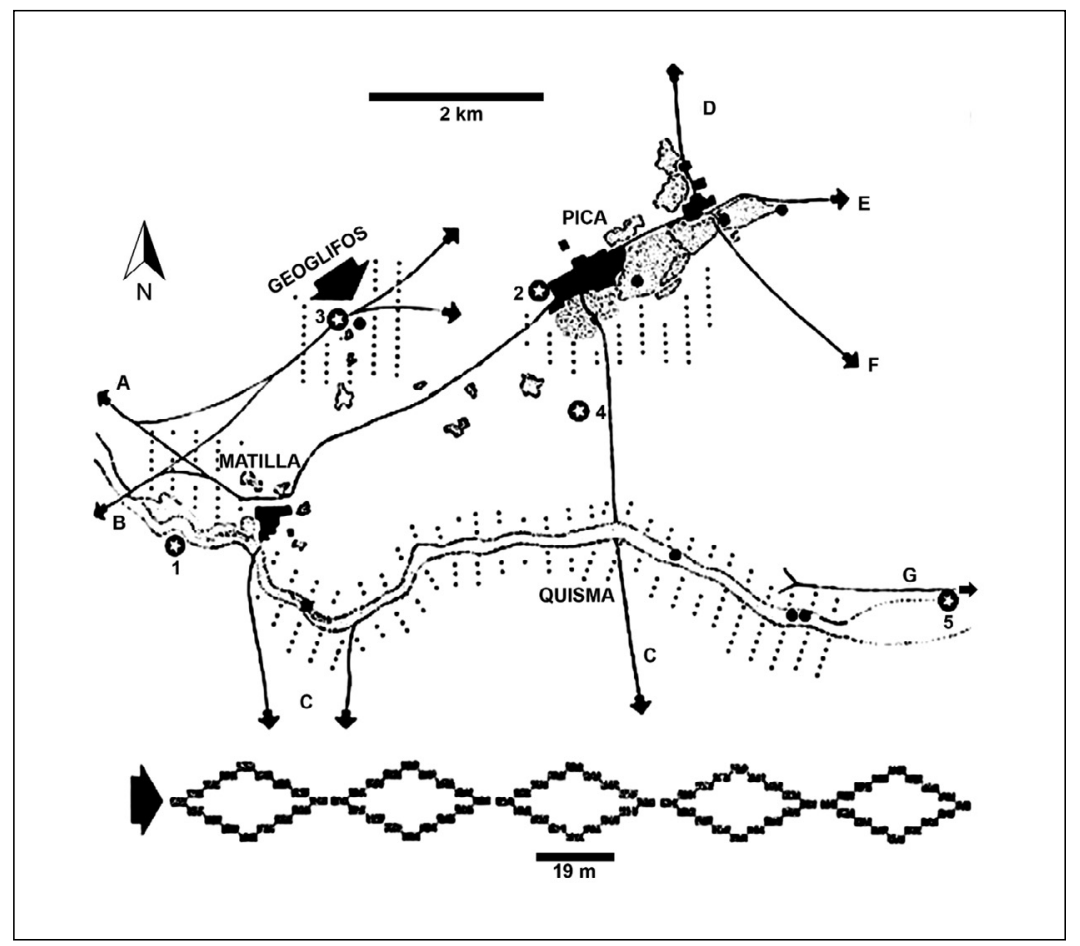

Figura 8. Referencias citadas en el texto.

$\star$ Principales cementerios citados: 1 (Pica-8); 2 (Pica-7); 3 (Pica-3); 4 (Pica-1). Pictografías El Salto (Pica-5). Interacción de rutas: A: Pica-pampa de Tamarugal - Tirana, vía costa. B: Geoglifos de Santa Rosita hacia los campamentos de Pintados, vía costa. C: Rutas hacia Puquio Núñez - Guatacondo - Quillagua. D: Ruta al valle de Tarapacá. E: Ruta a la laguna de Huasco, vía altiplano. F: Ruta a la cabecera del valle de Quisma, vía altiplano. G: Ruta a la laguna de Huasco, vía altiplano.

- Vertientes.

..... Zonas de ocupación.

tardías, en Bajo Molle a los 1407, 1402 y 1396 DC, por lo que se propone una plena sincronía entre cementerios y rutas de la conexión Pica-8/costa aledaña (Núñez 1974; Moragas 1995).

Estas rutas no siempre son directas entre los oasis y el litoral, sino que desde un nodo articulador, como es el caso de Pica, se observa un patrón que refleja diversas huellas multidireccionales que convergen entre oasis y desde aquí en un modo inverso siguen rutas divergentes que cubren hasta el Pacífico. El mejor ejemplo se advierte en la ruta que sale de Pica hacia la boca del Loa y Pisagua, reconocida por O'Brien en el siglo XVIII como: caminos del río de Loa y pesquerías de la costa (Hidalgo 1985). En estas ramificaciones el rol de los geosímbolos (geoglifos) en torno a la ritualización de los espacios debidamente electos fue clave para la memorización del mapa mental regional en términos de abras o pasos naturales, cerros de alta visibilidad, convergencia de vías, continuidad de explanadas y lugares con recursos.

En este caso solo se consideran las rutas trasversales de la modalidad "rastrillo", que descienden al litoral a través de paskanas (campamentos transitorios), geoglifos, ofrendas y cerámica del Complejo Pica-Tarapacá en rutas, y que cubren espacios desérticos de larga distancia entre Pica y Bajo Molle (ca. $85 \mathrm{~km}$ ), equivalentes a dos jornadas de días-luz, y Patillos (ca. $97 \mathrm{~km})$ a tres días-luz. Desde las salidas de las rutas de Pica se destacan grandes rombos escalerados en la única colina más cercana al oasis (Santa Rosita), otras lo hacen por el valle de Quisma (sector Botijería), orientadas a las paskanas y geoglifos de Pintados (Figura 8). Allí ascienden a nivel de la pampa Aerolitos en línea al cerro Pan de Azúcar con geoglifos 


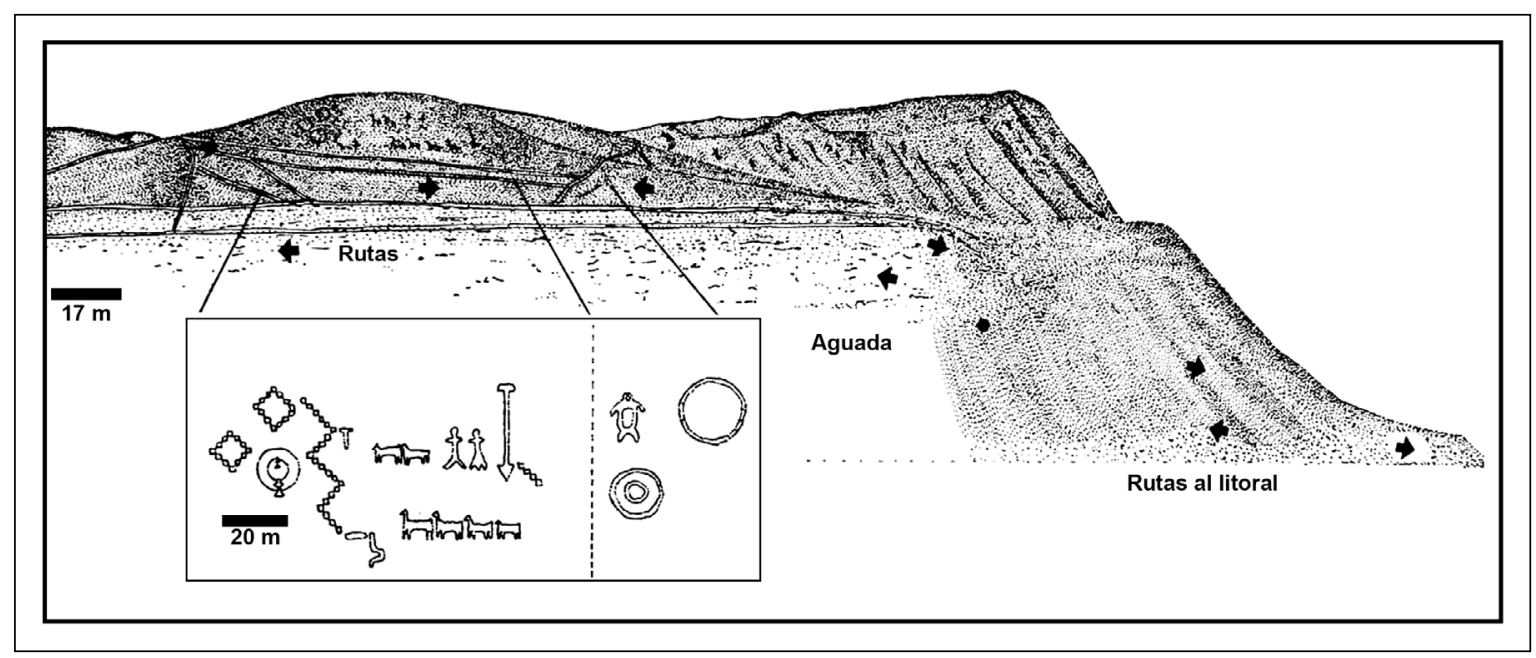

Figura 9. Las rutas del salar de Soronal se intruducen al Abra de Alto Barranco, donde se desciende al litoral del sector Caramucho. Los geoglifos representan a dos humanos asociados a caravana y rombos escaleradosPica-2.

similares, continúan en dirección al cerro Monos y desde allí al salar del Soronal, donde se establece un puerto de tráfico entre costeños y caravaneros, también con presencia del rombo escalerado. Desde aquí se acercan a la planicie orientada a la costa, enfrentándose a los geoglifos de Alto Caramucho, cuyos rombos marcan el abra que conduce a la aguada junto a los senderos que bajan hacia la caleta y guanera de Patillos (Figura 9).

Otra ruta hacia Patillos señala una conexión Pica-Tamentica-Puquillo de los Guatacondos, donde se bifurca al norte hacia Pozo Lagunillas-Norte, uniendo el cerro Carrasco con Patillos. La bifurcación al sur se une con el trazado Pica-Guatacondo y sigue por la quebrada de Pica, que desciende al sur del Pabellón de Pica (Bertrand 1885). El acceso a estas guaneras y pesquerías se advierte bien marcado con los geoglifos de Alto Guanillos con notables rombos escalerados, caravana de llamas, cuyas huellas asociadas vienen desde la conexión Pica-Guatacondo, introduciéndose en la encañada o paso natural por donde descienden a la altura del referente costero Boca del Diablo, junto a la guanera (Guanillos). Desde aquí el acceso a Chipana y boca del Loa es muy expedito por el borde costero. Otra conexión a Guanillos se ha identificado entre Pica y Guatacondo a través del cerro Cachango, donde la ruta se orienta hacia el Puquillo de Lagunillas-Salar Grande-Guanillos (Bertrand op. cit.).

Desde el nudo multidireccional de Pintados, salen rutas diversas como aquella que baja a Patillos con rumbo SW, pasando por los geoglifos del cerro Tentación. De allí hacia el norte del salar Grande donde se bifurca a Alto Patillos y su respectivo acceso a la caleta homónima. La otra continúa apegada al salar referido hacia la boca del Loa y utiliza las dos únicas bajadas existentes en el borde norte del barranco costero en el sector de la desembocadura.

Con respecto a la conexión Pica-Bajo Molle existe un punto de salida desde el asentamiento y cementerio tardío de Santa Rosita (Pica-3), junto a los grandes geoglifos rombos escalerados, hasta alcanzar un nudo de rutas en Cuminalla, con recursos propios del borde de Pampa del Tamarugal al sur de La Tirana. Desde aquí cruza el salar de Pintados por el borde norte y traza su rumbo por la encañada natural que alcanza los salitrales de San Enrique y el alto de San Antonio, hasta concentrarse en la aguada Yungay Bajo, otro puerto de tráfico con encuentros de rutas costa-oasis-costa en un abra con rombos escalerados. Desde aquí se orienta a Estación Central, otra vez con rombos similares, donde desciende a los senderos en zigzag que bajan a la caleta de Bajo Molle. Otra vía referida para esta misma conexión señala los siguientes puntos intermedios: Pica - Huayca - Tirana (Tamarugal) - La Noria - Las Rayas - el Carmen - Alto de la Bahía de Chiquinata y Bajo Molle (Bollaert 1975 [1860]).

Se suma un desvío desde Pica/Pintados que ingresa a las caletas contiguas de Río Seco y Pabellón de Pica. De acuerdo a las tradiciones conservadas en Pica, la quebrada de Río Seco se reconocía como de Pica, acorde a la misma 
posesión territorial ejercida en las guaneras de Pabellón de Pica, que debieron ser explotadas desde el Intermedio Tardío. Un desvío desde Pica-Tirana también se introduce al campamento caravanero y cementerio Yungay Bajo y de allí hacia Bajo Molle, sumándose a otra ruta que desciende a la costa de Bajo Molle - Iquique junto a los geoglifos "Bajada a Iquique" (Núñez 1976; Briones Ms.).

\section{Los campamentos de tráfico (paskanas)}

Las rutas de Pica más específicas hacia la costa arreica consideran locis ocupacionales intermedios importantes: cerros Pintados, cerros Monos, Pan de Azúcar y el salar del Soronal. A $36 \mathrm{~km}$ al oeste de Pica se sitúan los geoglifos de Pintados donde se han localizado campamentos caravaneros sincrónicos con evidencias explícitas de esta conexión costera. En Pintados-2 se han excavado restos de pescados, cuerdas de lana, conchas, carbón, fibra vegetal, cuerdas de pelo humano, plumas de aves de mar, cuchillos de lascas de sílice, lana de camélidos, vainas de algarrobo, calabaza, maíz y 311 fragmentos de cerámica del Complejo Pica-Tarapacá.

En Pintados 3 se han registrado dos depósitos socavados en la costra del salar que contenían una alta frecuencia de esquelones de pescados, los que fueron fileteados en la costa para ofrendar aquí solo los esqueletos completos, mientras que los marlos de maíces fueron desgranados probablemente también en la costa (Figura 10a-b). Es decir, los residuos alimentarios de ambos extremos del perfil traficado adquirieron valores simbólicos a juzgar por la presencia entre estas ofrendas, en cada uno de los socavados, de una pluma de guacamayo (Núñez 1985, Briones et al. 2005).

En su conjunto los productos de los oasis piqueños son elocuentes en estas paskanas: cerámica del Complejo Pica-Tarapacá, maíz (marlos, hojas y cañas), calabazas, frutos de chañar, algarrobo y coprolitos de llamas. Desde la costa provienen: conchas de almejas, ostiones, apretadores, locos, plumas de aves de mar, restos de lobo de mar, chuzos de huesos para mariscar y esquelones de pescados. Se integran cuchillos de sílice, cuerdas de pelo humano y de lana azul, mineral de cobre, restos de madera, malaquita y una lingotera cercana al depósito. Las rutas ascienden por la serranía de Pintados a nivel de la pampa intermedia y de allí se conectan con varios cam- pamentos caravaneros junto a geoglifos: cerro Monos y Pan de Azúcar, con dataciones sincrónicas con el Complejo Pica-Tarapacá y que reiteran los registros referidos en Pintados.

\section{El puerto de tráfico Soronal}

Estas vías continúan al salar del Soronal donde se sitúan extensas ocupaciones superficiales con restos líticos y conchas del Pacífico. El sitio Soronal-3 se corresponde con una formación monticulada artificial de unos 15-20 $\mathrm{m}$ de diámetro, donde se excavaron algunas inhumaciones a cargo de Ancker Nielsen en el año 1948 y un profesional no identificado que entregó dos cuerpos y sus contextos al Museo Histórico de Santiago hace varias décadas. En la prospección del año 1963 se revisaron inhumaciones en el montículo y más al sur donde se distinguió un cuerpo expuesto en posición extendida con camisón y ofrendas, como si se tratase de un fallecido en ruta (Núñez op. cit, Briones et al. op. cit.).

Efectivamente, las rutas se introducen al salar del Soronal ubicado a $21 \mathrm{~km}$ de la costa aledaña (caletas del Ñajo, Patillo y Caramucho), junto a recursos vegetales de grama salada/sorona (Distichlis sp.), aguada y geoglifos, destacándose el montículo referido. Ancker Nielsen (Ms.) recuperó objetos costeros y de oasis: huesos aguzados de arpones, puntas pedunculadas, lienzas con pesas, cuchillos enmangados, portacapachos, fragmentos de fajas, túnica listada, peines, sandalias, atado de cordelería, caracoles de mar, honda, cerámica miniatura, paños e hilos. De este cementerio proviene un portacarga escalerado completo con huincha para sostenerlo desde la frente, conservado en el Museo Histórico Nacional, donado antes del año 1961 por un ciudadano norteamericano no identificado (María Bichón, com. pers., excuradora del Museo Histórico Nacional). Es el mejor espécimen conservado en relación a sus contrapartes similares ubicadas en Pica-7, Caleta Huelén-12, entre otros. Al que usaba este portacarga se le ofrendó un tocado o diadema de plumas de "wajache" (Pelecanus thagus) con sus plumas atadas a palillos, homóloga a piezas de otros personajes costeños. Su registro en Chacance, en ese otro puerto de tráfico conectado con la boca del Loa, responde efectivamente a tradiciones costeras (Horta 2000; Agüero 2015). La colección de Soronal recuperada por Ancker Nielsen (Ms.) da cuenta de un contexto costero y de 


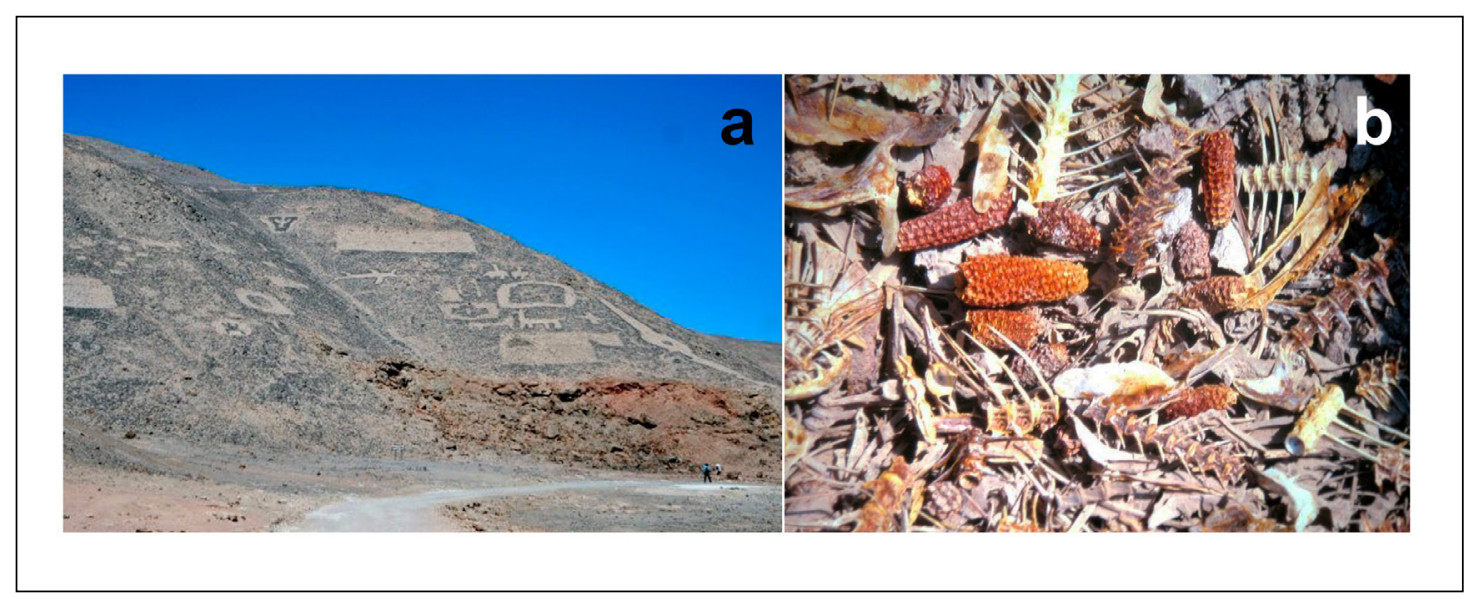

Figura 10. Relaciones entre geoglifos y ofrendas. A: Frente a los geoglifos de Pintados se han ubicado campamentos con restos domésticos y ofrendas. B: En el campamento 3 se registró un foso con ofrendas de maíces y restos de pescados, datados ${ }^{14} \mathrm{C}$ (ver Anexo).

oasis: arpones de hueso para pescados con barbas de espinas de cactus, cabecera de arpón de madera, atados de cordelillos, líneas de cuero de lobo para arpones, chopes de hueso para mariscar, plomada con lienza, puntas líticas de arpones, grandes anzuelos de cobre, astas y puntas líticas de flechas. La presencia de una bolsa, cubilete de hueso pequeño con tapa de cuero, vichuña o apretador de trama de telar y restos de maíz son evidencias derivadas de los contactos con el oasis de Pica.

Estos componentes costeros en un lugar dedicado a los encuentros con caravaneros provenientes de Pica se han constatado con sondeos posteriores (Núñez 1963, 1985; Núñez Ms.). Los tests realizados en este cementerio situado al este del salar dieron cuenta de cinco inhumaciones. Se trata de cuerpos genuflexos semioblicuos, registrados en la formación monticulada y sus alrededores. En un sector periférico de la elevación se documentaron rellenos en los fosos de las inhumaciones, compuestos de residuos costeros derivados de campamentos livianos que debieron situarse en la cercanía. Los contextos funerarios costeros, intactos y alterados, se remiten a bolsa con sandalias, portaarpón con acoplador, puntas de arpones de hueso para pescados con barbas de espinas de cactus, pesas líticas para anzuelos, rollos de líneas de cuero de lobo para arpones de madera, bolsa-red de fibra vegetal con equipos de pesca y caza, cerámica miniatura, portaarpón teñido de rojo y horqueta como pequeño horcón.
Entre los contextos vinculados con los oasis se numeran: arco miniatura, astas de flechas, camisones para los fardos funerarios, plato semiglobular, husos teñidos de rojo, estacas rojas señalando el entierro, punta de flecha pedunculada, vichuñas de hueso, bolsas con lana y semillas no identificadas. Se suma el peinado con trenzas separadas y embarriladas con lana, siguiendo el patrón de Pica-8, además del enfardamiento a base de ojales unidos por cordelillos que aprietan el paquete funerario y la disposición de dos camisones en un cuerpo. Con respecto al cuerpo extendido y no enfardado, fallecido en ruta y trasladado a Soronal, sobre los pies tenía ofrendas de maíces, conchas marinas y espinas de pescados, además de tapones cilíndricos de madera con extremos agudos similares a los registrados en la paskana de Pintados. En la zona pectoral un yesquero para hacer fuego, una punta lítica foliácea denticulada de arpón y un arpón de hueso para pescados menores con un típico patrón de barbas salientes de la misma pieza (Figura 11a-b).

Se realizó un test cronoestratigráfico en un depósito aledaño al montículo de Soronal-3 para los efectos de contrastar los datos funerarios con las ocupaciones. Al respecto se reconoció un patrón de estratificación de ocupaciones intermitentes con capas delgadas resultantes de residuos de corta duración de origen costero e interior, entre restos de pescados, mariscos y maíces en lo principal de acuerdo a los contextos funerarios. Una datación del orden de los $1450 \mathrm{cal}$. AP, 1360 a $1300 \mathrm{AP} / 650$ a 980 
DC, lograda en el nivel medio del depósito, da cuenta de encuentros con mayor frecuencia entre gentes de la costa y caravaneros, acorde con las fechas más tempranas conocidas entre Pica-8 y el litoral. Se asume que el comienzo de este depósito ocupacional no fechado sería anterior a esta datación e indicaría que estos encuentros a $21 \mathrm{~km}$ del litoral y a $60 \mathrm{~km}$ de Pica pudieron ocurrir algo antes del Intermedio Tardío (Briones et al. 2005).

Un examen general de estas evidencias sugiere que ciertas agrupaciones costeras y de oasis instaladas en el litoral pernoctaban en este "puerto de tráfico" toda vez que la altura (cuenca en la cordillera de la Costa), el recurso de agua y la vegetación creaban un ámbito favorable para evitar el descenso de las caravanas al piso cálido del litoral. Aquí se establecerían las operaciones de carga y descarga junto a los rituales en torno a los geoglifos, donde se destaca un panel precisamente con aves marinas. Este encuentro entre costeros y caravaneros con indicadores culturales piqueños debió ocurrir con suficiente continuidad a juzgar por la locación de restos de ocupación profunda y estratificada con residuos muy laminados, de acuerdo con los intervalos entre encuentros junto al pequeño cementerio constituido de costeros y vallesteros fallecidos en rutas o in situ.

En general las vías del tráfico trascurren por lugares transitorios de descanso vinculados con prácticas rituales junto a geoglifos, o con los fallecidos y ritos propios de los traslados transdesérticos, con ofrendas en "coveros" (socavados ceremoniales) o bajo leves promontorios. Sin embargo, en Soronal se han situado acciones más complejas en un espacio de encuentro interétnico que se ha interpretado como un "puerto de tráfico" (Núñez 1963, 1985; Núñez Ms.). Responde a aquellos que se sitúan en la periferia de los asentamientos estables u otros lugares neutrales costeros o interiores con mejor infraestructura. Al adaptar de Chapman (1976) la noción de "puerto" como los puntos tradicionales de convergencia de las redes viales de larga distancia, es posible identificar dónde se procede a pernoctar, descargar, cargar o transar en un espacio neutral, equidistante o no de los asentamientos - ejes internodales, pero dispuesto en el rumbo y ambiente adecuados. Se trata de lugares vacíos que contienen disponibilidad mínima de agua, forraje, protección y recursos para acoger campamentos donde las caravanas y cargadores pernoctan y establecen sus tratos, arribados

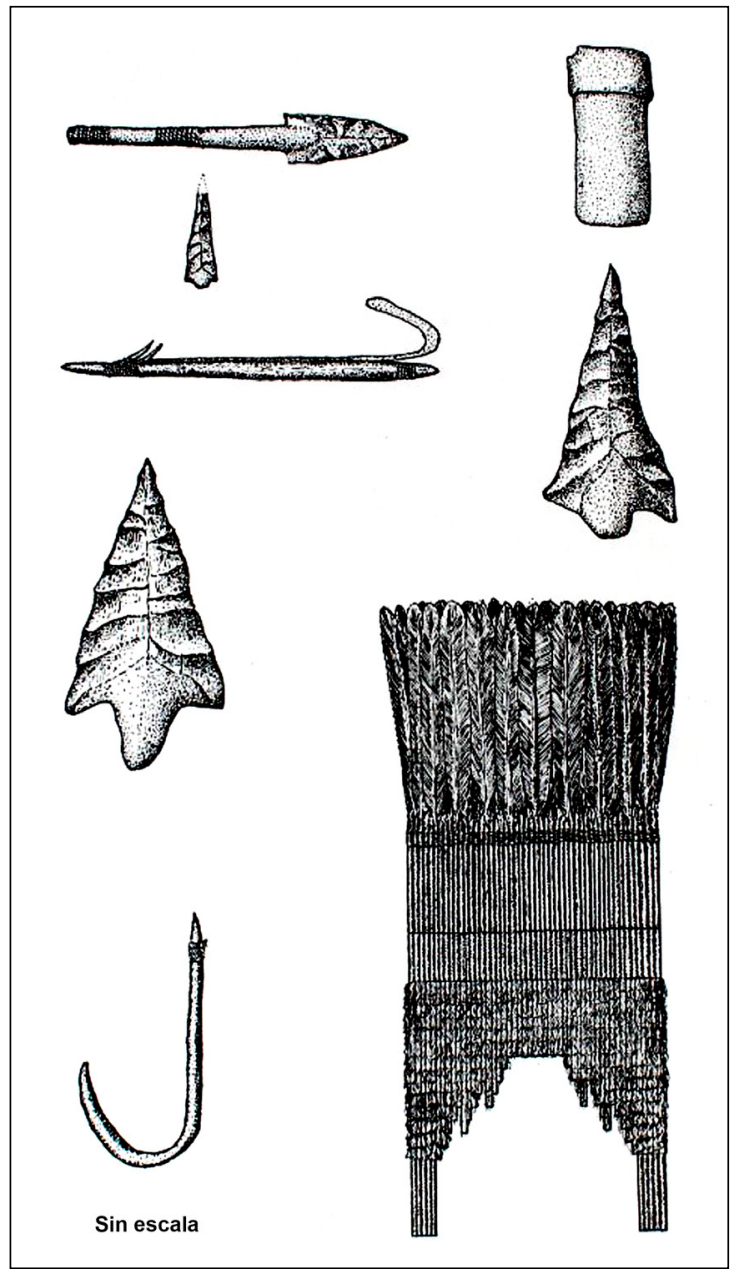

Figura 11 a-b. En el puerto de tráfico del salar de Soronal se registraron junto a evidencias caravaneras inhumaciones con contextos de oasis y costeros, como los expuestos en esta figura.

desde diversos lugares, incluso la inhumación de los fallecidos en ruta. No son espacios productivos en sí mismos, sino más bien acogen en este caso a grupos transitorios peatonales costeros con llameros de los oasis, reflejados en su materialidad y recursos diferenciados, durante tiempos sincronizados de interacción. Soronal presenta estos atributos con la oferta además de basalto y sílice aplicados en la costa desde tiempos arcaicos, sumado a la aguada, combustible y forraje cercano al litoral.

El segundo caso es el campamento Yungay Bajo, ubicado a $20 \mathrm{~km}$ de la costa (aprox.), también con residuos costeros y de oasis, asociado a geoglifos y un sector con inhumaciones de gentes que traficaban desde y hacia sitios 
costeros entre Pica y los asentamientos de Patillos y Bajo Molle con textiles del patrón Pica-8 (Sanhueza 1985). Por cierto que aquí también se ubica una aguada junto a un reducido cementerio con restos de actividades domésticas (campamento). El lugar fue seleccionado además por constituirse en un abra ritualizada con geoglifos que permite el paso más holgado de las rutas que se concentran aquí antes de dirigirse a diferentes objetivos multidireccionales. Una sale de Rinconada de Yungay al litoral aledaño, otra al SW se integra con una importante huella proyectada hacia Bajo Molle.

\section{Los geosímbolos}

Al observar en la mayoría de estos campamentos y rutas la frecuente distribución de los geoglifos con rombos escalerados, se advierte que responden y caracterizan al espacio y tiempo del tráfico del Complejo Pica-Tarapacá. Se sitúan entre los valles, oasis y quebradas bajas que conducen preferentemente al litoral, cubriendo los espacios vacíos de interfluvio. Se configuran como un semiarco que une los asentamientos agrarios de Tarapacá, Pica, Guatacondo y Quillagua, bajando a la costa desde Pisagua a Tocopilla, donde se destacan las locaciones de interacción que incluyen los enclaves de Bajo Molle y Patillos.

La única orientación diferente a este patrón es la conexión desde Quillagua a Chug Chug y Calama donde interactúan las fronteras laxas de los componentes PicaTarapacá con el Loa medio / superior y Atacama. Esta conexión se estableció a través de dos rutas desde Quillagua: a) Chacance - río San Salvador - Calama; b) Chug Chug - Calama, proveniente de Tarapacá, Pica, Maní, Chelis y Guatacondo (Bertrand 1879). Un aspecto que llama la atención entre las mayores concentraciones de geoglifos tarapaqueños es la particular elección de relieves adecuados, justo donde la vialidad evita ser trazada por terrenos abruptos o más extensos. En este sentido la opción de Pintados como Yungay da cuenta del paso más adecuado, como lo es también el caso muy representativo del abra de Chug Chug (Pimentel 2013).

Fuera de dudas, la presencia de geoglifos con rombos escalerados marca las principales rutas de interacción entre los oasis interiores y la costa, distribuidos de norte a sur: Unita, tramo inferior de quebrada de Tarapacá, Yungay Bajo, Pica, Alto Guanillos, Alto Caramucho, Lomas de
Calera, Chacarilla, quebrada de los Pintados al sur de Tamentica, quebrada Cahuiza, quebrada Chipana, Chug Chug y otro más próximo a Calama (alterado), finalmente en cerro Posadas cerca de Tocopilla. Estos conjuntos marcan los descensos al litoral desde quebradas y oasis interiores, distribuidos desde el sur de quebrada Camarones hasta la cercanía de Tocopilla y Calama. No caracterizan a los Valles Occidentales de la cultura Arica y, por el contrario, ritualizan el tráfico precisamente en el territorio originario del Complejo Pica-Tarapacá durante el Intermedio Tardío.

Precisamente las rutas y los rombos escalerados tipifican los contactos piqueños con el litoral. Se reconoce que el conjunto más monumental elaborado en Pica corresponde a cuatro grandes diseños y dos más reducidos en una de las pocas colinas junto a Pica-3 (Santa Rosita), donde salen senderos multidireccionales. Al no registrarse al este los rombos escalerados o en cotas más altas, alejados de los oasis tarapaqueños, se sugiere que fueron realizados por grupos locales especializados en mantener los circuitos caravaneros en la vertiente occidental. Rombos similares son comunes en los diseños de cestería, textilería y otras artesanías de los cementerios piqueños, de modo que no debería extrañar que los traficantes tarapaqueños-piqueños elaboraron estos geosímbolos que visualizaban su propia identidad caravanera.

El liderazgo del Complejo Pica-Tarapacá y sus comunidades asociadas construyeron una geografía ritualizada, integrando diversas fajas transversales de interacción que incluyeron recursos sociales y económicos complementarios. Para este efecto mantenían un código simbólico compartido intervalles tarapaqueños con énfasis en sus conexiones con el litoral (Figura 12a-b). En estas operaciones procedieron a la apropiación geosimbólica del espacio, animándolo de una intensa ritualidad visual y significándolo con íconos identitarios a través de lecturas compartidas. Se trataba de llenar los espacios vacíos con sus idearios emanados desde la soledad de las travesías y las tensiones asociadas no exentas de riesgos, que incluyeron hasta la muerte en ruta (Torres-Rouff et al. 2012b). Hicieron de sus itinerarios una prolongación del ethos de sus comunidades y con ello cubrían las necesidades de protección y buenaventura en las dos a tres jornadas-luz de bajada, con un promedio de 30 a $40 \mathrm{~km}$ de recorridos diarios que trascurrían entre Pica y la costa. 


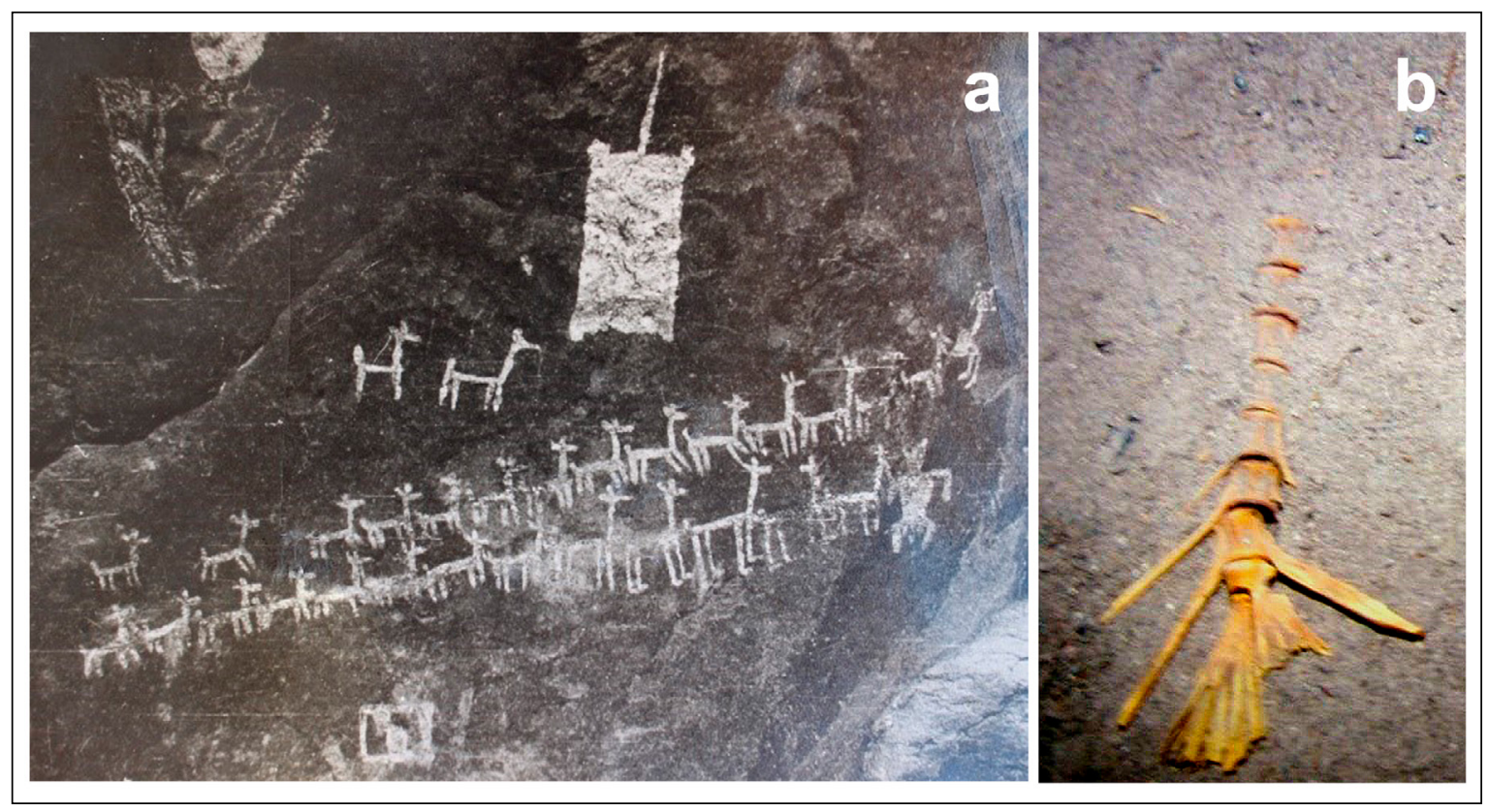

Figura 12.A: A: Pictografía en blanco de caravanas y un esbozo de rostro y túnica trapezoidal diseñada en el sector superior izquierdo, representativa del cementerio Pica-8. Se ubica en la cabecera del valle de Quisma. B: En el decapado del piso se registró una ofrenda correspondiente a un esqueleto de pescado.

Se procedió a sacralizar los espacios de interacción, concentrándose la mayor distribución de geoglifos entre Camiña y el Loa, situación que refleja la apropiación de un espacio intermedio de movilidad articulado por élites locales jerarquizadas (Bonnemaison 1981). Esta forma de integrar los oasis y valles segmentados e inconexos con el litoral relativamente cercano exigió de trazados de rutas con geoglifos que cruzan espacios vacíos de aridez absoluta entre serranías y salares a través de explanadas afines al movimiento caravanero. Situación distinta al desierto más absoluto entre Tocopilla y Taltal, donde la carencia de geoglifos se explicaría por la ausencia de valles y oasis cercanos al litoral y el uso eventual de ritos de movilidad diferentes a los patrones tarapaqueños entre los oasis atacameños vía Peine - Imilac - costa.

Es muy seguro que los diseños geométricos de los geoglifos, como la textilería, explicitaban mensajes y visiones concretas de difícil interpretación actualística. No así aquellos temas que reflejan objetivos susceptibles de ser "leídos" hoy. En relación a los datos expuestos, es posible plantear que aquellos que marcaron los diseños de la fauna marítima, lo hicieron con un pleno conocimiento que resulta de hechos observados en la realidad costera. Ciertamente, se distinguen varios geoglifos con peces diferentes, específicamente desde Pica a la costa: cerro Vertedero, cerros Inti, Cuevita, Cerros Pintados, salar de Soronal, y por sus diseños en la serranía de Chug Chug es posible asegurar que a lo largo de la conexión costa-Loa transitaban gentes que también permanecían por largo tiempo en la costa. En general, al observar los peces y balseros representados se reconoce un detallado conocimiento de escenas y clases específicas de peces, ejecutadas por artífices que precisamente a raíz de sus residencias prolongadas en la costa participaron y captaron imágenes propias de la vida cotidiana del litoral y de los oasis, transformándolas en los íconos de sus desplazamientos (Figura 13).5 Sabían reproducirlas, ya que habían convivido con escenas epopéyicas dignas de ser perpetuadas, como los arponeos de grandes peces desde balsas, que hasta ahora son los actos más prestigiados y exaltados por los pocos cazadores relictuales de albacoras, continuadores del oficio, ejecutados desde los últimos "faluchos" cuando no contaban con los puentes de proa (René Bolados, com. pers.).

5 Con las fotos de geoglifos de peces a la vista, diversos expertos lograron identificar por sus aletas dorsales y otras características a varias especies, correspondientes a grandes presas. 


\section{GEOGLIFOS ICTIOMORFOS ESTILO TARAPACÁ}
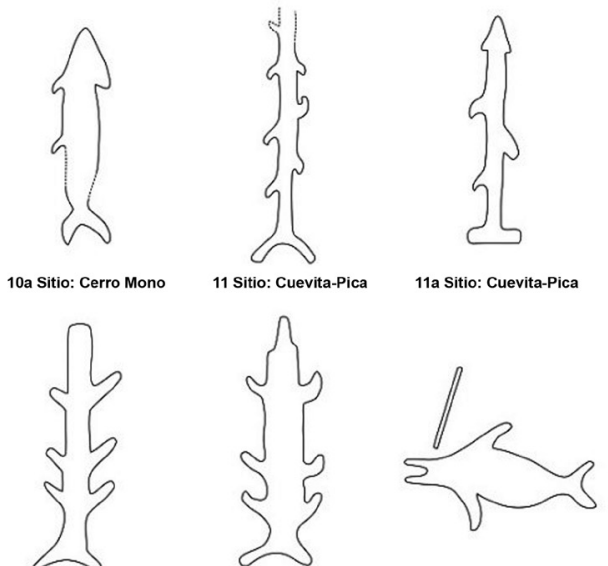

11b Sitio: Cuevita-Pica

11c Sitio: Cuevita Pica

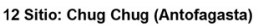

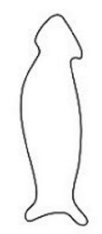
13 Sitio: Alto
Ariquilda
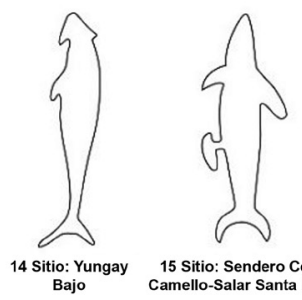

15 Sitio: Sendero Cerro Camellio: Sendero Cerro Bajo mello-Salar Santa Lucia

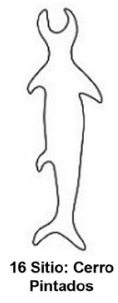

Sin escala

Figura 13. Geoglifos ictiomorfos correspondientes a grandes peces usualmente capturados por arponeo, ubicados junto a rutas caravaneras en distintos espacios entre la costa y los oasis.

En consecuencia, los hacedores de geoglifos ictiomorfos también replicaron a camélidos y caravanas, por cuanto aspiraban a combinar las imágenes más prestigiosas, sintetizadas en una cosmovisión caravanera que compartía los dos mundos opuestos e integrados a la vez. Un testimonio de un modo de vida vigente en ese momento prehispánico, cuando ciertas agrupaciones de oasis se instalaban por tiempos prolongados en el litoral. Esto explica el detallado diseño de los peces elaborados a lo largo de sus rutas, destacándose principalmente las aletas de peces de gran envergadura. Los datos etnográficos costeros recogidos han recalcado el rol de esos "capachos" como señal de abundancia y acercamiento a peces de grandes tamaños, para la identificación del porte y la estrategia de enfrentamiento de lo que será o no su presa elegida. Hay consenso que la mayoría representada corresponde a peces sujetos a las prácticas de arponeo. Es decir, hay una cerrada relación con las imágenes de balseros que arponean observados en los paneles con geoglifos y petroglifos. Esto significa que quienes lo hicieron tenían un conocimiento detallado de cada presa y con ello se debería asumir que las largas permanencias junto a las tareas costeñas les permitieron a los piqueños integrarse a las labores a cargo de los especialistas locales y con ello incorporar a su memoria los peces de mayor valor simbólico.

Es posible asegurar que los últimos geoglifos elaborados junto a las rutas prehispánicas se ejecutaron durante invasión española, cuando aún se sabía cómo hacerlos y se valoraban hechos gravitantes que marcaban la memoria colectiva. El registro de un geoglifo monumental situado cerca de Guatacondo, con una narrativa histórica compuesta por personajes con atavíos del siglo XVI, junto a fauna europea, da cuenta de un episodio realmente observado o memorizado y luego ejecutado. Se trata de una misión de españoles que acompañan a un grupo de indígenas prisioneros, dominados o atados a una viga (Clarkson y Briones 2001).

De la misma manera como en el espacio del desierto occidental, en el ámbito de los geoglifos no se advierten las grandes apachetas, a pesar de que éstas se asocian directamente a rutas "rastrillo" de larga distancia, es plausible aceptar que quienes las levantaron gradualmente y las ritualizaron son aquellos que trafican al este de los oasis. En el caso de Pica, las más cercanas y monumentales se sitúan a $45 \mathrm{~km}$ (Mama apacheta) y eran y son ofrendadas a la salida y llegada de las caravanas. Esto significa que sería posible que el tráfico de larga distancia compartiera un ideario religioso bivalente. Los geoglifos como los marcadores con más carga simbólica o figurativa, válidos en las tierras bajas, mientras que las apachetas se valoran en el espacio serrano-altiplánico, en donde las comunidades de valles no ejercían control directo en espacios sociales más abiertos con ritos viales compatibles con idearios agropastoralistas de tierras altas (Figura 14).

\section{^ LAS INTERACCIONES CON LA COSTA DURANTE EL DOMINIO INCA: EL CEMENTERIO PICA-7}

La irradiación inca cuzqueña ocurrió desde el centro administrativo de Tarapacá Viejo, implantado en el espacio político más importante del Complejo Pica-Tarapacá. Por la vía caravanera preexistente que unía la quebrada de Tarapacá con Quillagua se consolidó el dominio inca en 


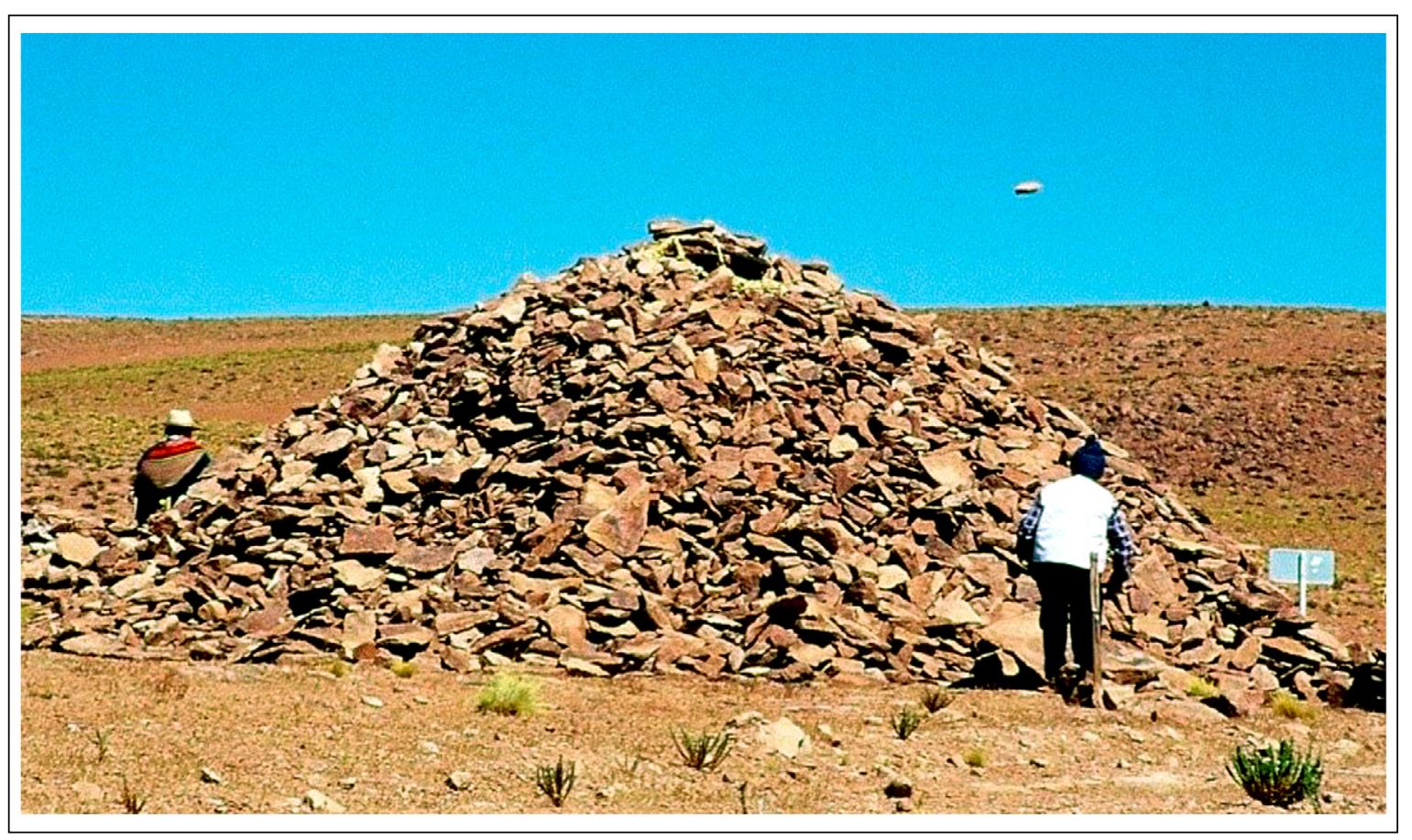

Figura 14. Apacheta asociada a las rutas caravaneras del circuito Pica - altiplano, ubicada a $30 \mathrm{~km}$ al este del oasis.

el oasis intermedio de Pica. Al considerar que los incas condujeron localmente la explotación de minas cercanas tan altas como Collahuasi (cobre) y junto al Pacífico en Huantajaya (plata), es admisible aceptar que junto a los líderes locales evaluaron los recursos tarapaqueños y aun intentaron el incremento de regadío para ampliar la producción minero-metalúrgica y agraria con aguas trasladadas hacia la Pampa del Tamarugal (Lozano Machuca 1885[1581].

En consecuencia, el aparato y control administrativo inca fue directo con autoridades cuzqueñas asociadas a las locales, estableciendo conexiones con el altiplano meridional a juzgar por las ofrendas frecuentes de la cerámica Pacajes/Carangas en los Valles Occidentales. Estas conexiones altiplánicas derivarían del acceso de agrupaciones preincaicas enviadas desde los señoríos aymaras y que continuaron insertas en las políticas del Estado inca por medio de mitmas que pervivieron durante el contacto histórico en la misma encomienda donde se insertaba Tarapacá. De hecho, estos movimientos de alteños y sus acomodos corresidenciales entre comunidades locales han sugerido componentes multiétnicos al interior de la sociedad dominante Arica-tarapaqueña que constituía la matriz étnica mayoritaria en las tierras bajas (Hidalgo y Focacci 1986).

La presencia de la administración inca en Pica se vincularía con el control, entre otros, de los recursos de la producción costera. El rescate del cementerio Pica-7 viene a precisar la valoración del tráfico de productos marinos y su intensificación hacia los oasis y sus conexiones con las tierras altas. Se trata de una agrupación especializada en la explotación costera, enterrada en su propio cementerio de extensión discreta del orden de los $250 \mathrm{~m}^{2}$. Presenta piezas incas: topus, keros en madera grabados o con diseños volumétricos, escudilla de madera, gorros semiglobulares con penachos y aríbalos locales monocromos. Se encuentra retirado de los cementerios del Intermedio Tardío y de las vertientes, esto es, marcando un espacio periférico. Por el hecho de enterrarse en este oasis se asume que mantenían un asentamiento estable directamente vinculado con el tráfico costero, asociado a la cerámica Saxamar con diseños de llamitas negras estilizadas. Se incluyen los componentes locales del Complejo Pica-Tarapacá a través de las escasas inhumaciones de infantes introducidos en grandes cántaros globulares partidos e invertidos, platos semiglobulares, cestería coiled, maíz, 


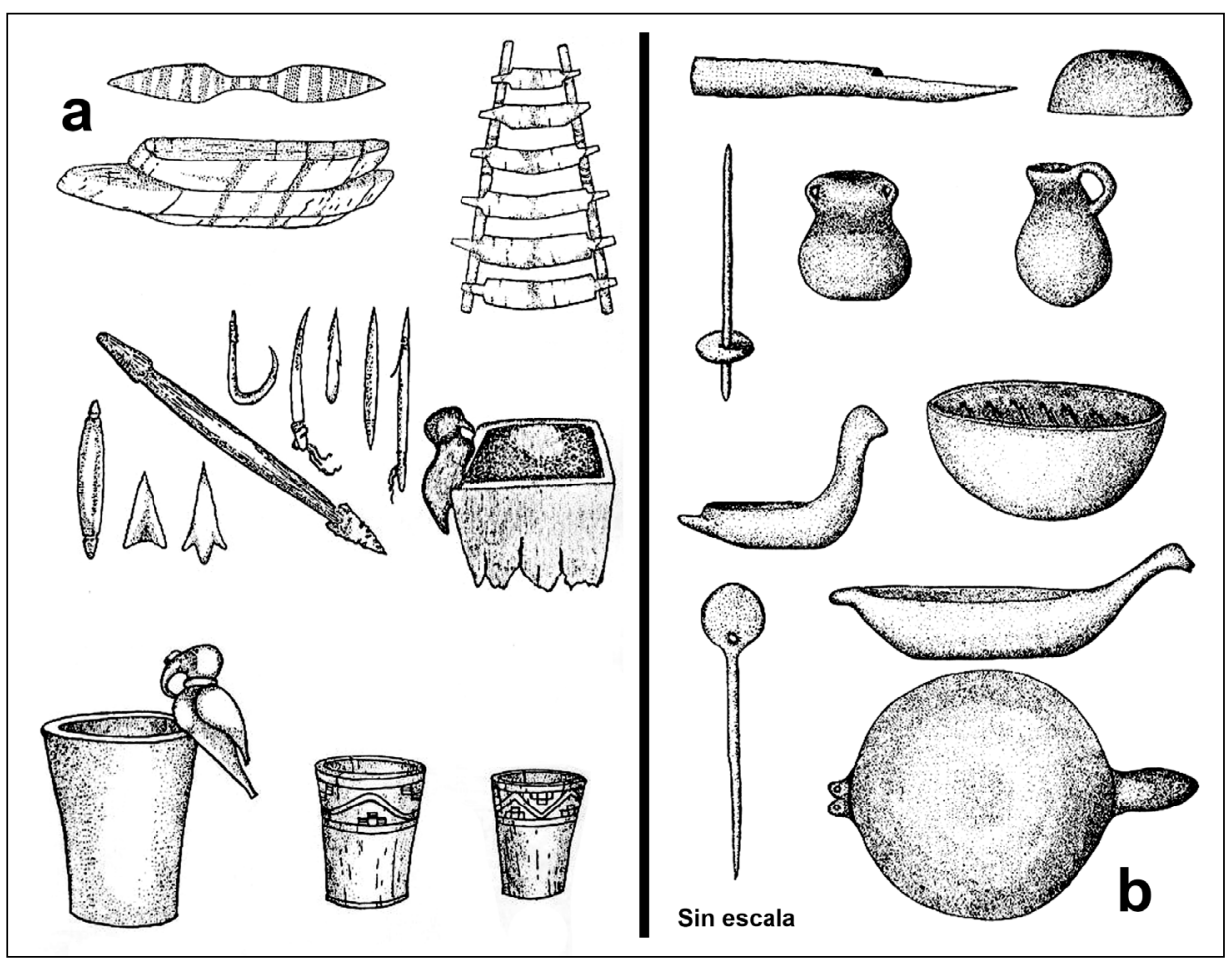

Figura 15. Contextos del cementerio Pica-7 con componentes incas. A: En la parte superior se advierten implementos costeros de uso preinca, incluyendo en el extremo derecho el portacarga escalerado, suspendido desde la frente, distribuido entre la costa y los oasis. En el plano inferior se observan diversos cubiletes de madera de data inca. B: Escudillas y prendedor inca asociado a contenedor cerámico del tipo Saxamar con dibujos de llamas negras, y otros utensilios locales: cencerro, vasijas miniaturas, huso de hilar y vichuña de telar.

peines, cencerros, vichuñas y equipos de telar. Se distinguen ofrendas emblemáticas costeñas de origen preinca: balsa de tres cuerpos y remo miniatura pintados transversalmente de rojo, cabeceras de arpones de madera y hueso, puntas líticas de arpones, grandes anzuelos de cobre y pesas de pesca, entre otros (Figura 15a-b). La presencia de portacarga escalerado asociado a un adulto con objetos netamente costeros, semejante a otro registro de Soronal y aquellas tablas asociadas de Bajo Molle, Patillos y caleta Huelén, demostraría que el uso de caravanas se habría complementado con este ingenio de carga individual que marca seguros contactos con el litoral, antes y durante los incas (Núñez 1962; Núñez Ms.).

Es posible que la información recibida por los incas de la élite local no solo valoró los recursos mineros argentíferos (Checura 1977; Núñez 1979), sino también la riqueza marina excedentaria. De hecho, la explotación de la mina del Sol (Huantajaya) se realizó por la ruta preexistente Tarapacá - Mapocho - Huantajaya - costa de Iquique. De- finitivamente los incas evaluaron los recursos del litoral y la riqueza metálica, al punto que celebraron en una cumbre sobre Iquique rituales de inmolación y ofrendas en el cerro Esmeralda, cerca de las minas de "Tarapacá" (Huantajaya) con vista de frente al mar. Se ofrendaron cerámicas cuzqueñas y del altiplano meridional: Saxamar/Inca Pacajes-Carangas (Ryden 1947), a cargo de la élite inca establecida en Tarapacá Viejo (P. Núñez 1984; Urbina 2007). La experiencia local derivada del caravaneo costero durante el Intermedio Tardío se habría intensificado en Pica durante los incas, organizándose esta vez una comunidad de pescadores especializados (Pica-7), sin dependencia de las labores agrarias, que logró apropiarse de las tecnologías costeras, incluyendo sus embarcaciones eficientes de data preincaica. ¿O se trató de una colonia de pescadores organizada por la administración inca para optimizar el tráfico de productos marinos, con sede operativa en el oasis? Al inhumarse con pucos Saxamar se asume que continuaron las conexiones con las tierras altas. 
Se propone en consecuencia que en los oasis de Pica radicaba una élite inca que debió administrar entre otros recursos el tráfico de bienes costeros en los tiempos de la gentilidad (Hidalgo 2000). Estas orientaciones económicas persistieron durante el temprano régimen colonial. Cuando se territorializa la provincia de Tarapacá, en el año 1538 , se incluía en los valles bajos y serranos a indios pescadores, señalándose en la visita del virrey Francisco de Toledo que entre los años 1570 - 1575 se había iniciado la reducción de los indios de Pica y del Loa en un espacio común (Cúneo Vidal 1915). De modo que a 14 años de la invasión europea, en la formación de la encomienda tarapaqueña, los indios tributarios lo hacen con productos que responden a la interacción de data prehispánica: "piezas" de algodón de los oasis (ivestimentas?) además de pescados secos y salados (Trelles 1991).

\section{$*$ Conclusiones}

En distintos espacios del desierto de Atacama se ha demostrado el rol de la movilidad caravanera con diversas variables que no solo han considerado la trama de los trazados viales sino contextos explícitos valorados en su mérito (Núñez 1976; Berenguer 1994; Briones et al. 2005; Cases 2004; Pimentel et al. 2011, entre otros). Desde este enunciado se propone que la organización sociopolítica tarapaqueña de este período pudo ordenarse en la forma de un señorío macro y multiétnico no estatal (Rostworowski 1999), con autoridades que conducen un territorio segmentado física y socialmente, con atributos compartidos: culturales, religiosos, biológicos, lingüísticos y de atuendos. Se habría logrado un equilibrio entre el sedentarismo agrario y artesanal con la circulación de larga distancia de bienes de consumo y uso cotidiano, de prestigio y ritualísticos aplicados a la visualización del poder. El Señorío se habría sostenido con el manejo y movilidad de excedentes agrarios, materiales, vestuarios, artefactuales y parafernálicos, con acciones más corporativas que coercitivas, donde la complejidad social se alterna con fuerzas dicotómicas desiguales (Chapman 2010). $\mathrm{Al}$ respecto, la regularidad de ciertas ofrendas icónicas y su distribución extralocal (p.e. tocados y camisones) da cuenta de autoridades con acciones descentralizadas que operan en un amplio territorio multicomunal, asociado a artesanías, vestimentas y ritos rupestres con símbolos e identidades compartidas (Robb 2010).
Dicho lo anterior, los caravaneros piqueños fueron segmentos móviles al interior del espacio Pica-Tarapacá, que incluyeron desplazamientos hasta sus fronteras, acompañados de ritualización y marcación de rutas internodales. Mientras tanto, en los asentamientos nucleares y los limítrofes vinculados se compartieron claves simbólicas asociadas a la circulación de ritos, bienes, productos y ropajes identitarios usados por personajes locales y aliados, que visten con los íconos y formas de las cabeceras políticas. Esta modalidad explica la fluidez del tráfico, la carencia de conflictos extendidos y el reconocimiento de los nodos costeros más productivos, al percibirse las ventajas de articular con los asentamientos agrarios en momentos en que sus excedentes se han incrementado en un marco de relaciones con intereses recíprocos.

Al seguir las propuestas sobre movilidad tras la obtención de recursos extralocales complementarios (Murra 1972; Núñez y Dillehay 1979), es posible argumentar la forma en que pudo organizarse el territorio tarapaqueño antes de los incas. Inspirándose en el modelo de Harris (1983) es probable que las élites constituyeran largas fajas transectuales donde integraron diversos enclaves productivos, en este caso desde el borde occidental del altiplano al litoral. No se requería movilizar colonias a espacios complementarios ajenos. Más bien fue posible incluir gentes y espacios al interior de la comarca étnica a través de una compleja red de rutas y pactos de interacción.

Entre el sur de Pisagua a la boca del Loa se privilegiaron los lugares con puntas y caletas productivas con vertientes y cúspides receptoras de aguas de neblinas. A diferencia de la costa exorreica de los valles de Arica, conectados al Pacífico, aquí durante el Intermedio Tardío la costa arreica fue interdigitada por rutas transdesérticas desde los valles y oasis fértiles interiores, puesto que abajo había localidades costeras prestigiosas con comunidades tecnológicamente eficientes, asociadas a instalaciones, cementerios y aguadas que actuaron como centros de convergencia (Núñez y Varela 1967-8).

Por las evidencias isotópicas referidas y los contextos funerarios, es posible aceptar que en Pica-8 fueron enterrados ciertos individuos que se alimentaron preferentemente con productos marinos. Éstos habrían pernoctado largas temporadas en el litoral o, en su defecto, otros no se movieron de los oasis y consumieron lo mismo, de 
modo que hubo eventos de traslados de gentes, recursos y cultura material entre los oasis y la costa.

Se deduce que el manejo de caravanas fue el medio principal para optimizar el traslado de recursos en esta comarca. Los datos etnohistóricos y etnográficos acuerdan que se movilizaban recuas llameras de carga en las tierras bajas y el litoral local con el traslado de guano y pescados tratados (Acosta 1940 [1590]; Cieza de León 1962 [1554]; Vazquez de Espinoza 1948 [1628]. Se mantenían las caravanas bajo sombra en recintos localizados en los tambos de Pica hasta la mitad del siglo XX, procedentes del altiplano limítrofe y por lo mismo es posible que se hubieran criado en los oasis en tiempos prehispánicos a escalas discretas, reproducidas con forraje local de maíz y algarrobo, de acuerdo a los registros documentados en las paskanas intermedias al litoral (Briones et al. 2005). Las evidencias zooarqueológicas e isotópicas de llamas en contextos formativos-urbanos en los valles costeros del norte del Perú aprueban una crianza in situ, en ambientes costeros cálidos y húmedos precisamente con forraje algarrobero (Shimada y Shimada 1985, Vásquez Sánchez et al. 2012).

En el litoral arreico, desde la etnografía se pueden percibir sensibles eventos de escasez por bravezas concentradas en invierno, desembancamiento de fondos, aguajes tóxicos (irihue), entre otros; sin embargo, la tendencia ha sido obtener siempre más recursos de los necesarios con técnicas de secado y salado. En los valles y oasis interiores la carencia de agua, abonos, efectos aluvionales y otras anomalías no limitaron sus excedentes asociados a prácticas de bodegaje de granos, secado de carne y tuberosas además de la elaboración de harinas. Lo importante es que ambas fuentes alimentarias eran valoradas recíprocamente y se lograban a través de arreglos interétnicos (intercambios) y coexistencia de agrupaciones costeras y de oasis, en enclaves productivos compartidos en el litoral: patrón de ocupación corresidencial transitorio. En verdad, estas cabeceras de oasis estaban localizadas a distancias discretas de los recursos costeños y andinos, actuando como puentes intermediarios con productos particulares.

Para comprender estas conexiones, los contextos del cementerio Pica-8 con aquellos costeros de Bajo Molle y Patillos han demostrado la alta presencia de materia- lidad piqueña sincrónica en el litoral aledaño a través de geosímbolos, ofrendas, rutas, paskanas, ritos y puertos de tráfico. Por otra parte, los análisis de isótopos, biológicos y de contextos funerarios de Pica- 8 señalan precisamente que existió un descenso de gentes, componentes culturales y productivos del Complejo Pica-Tarapacá al litoral, al interior de un régimen de convivencia donde los enterrados en la costa, foráneos y locales, lo hacen con el utillaje propio de las labores costeras junto a los contextos de oasis, y los que retornan a sus cabeceras y se entierran en Pica-8 lo hacen después de haber mantenido dietas costeras prolongadas, sin acompañarse de ofrendas de origen costeño, sino con aquellas de su identidad original.

Este escenario de movilidad intermitente se apoyó en una intensa ritualización geosimbólica con estilos rupestres tarapaqueños, elaborados para perdurar en el tiempo, sacralizándose los accesos más logísticos, los rumbos adecuados desde los valles, quebradas y oasis bajos entre sí, visualizando paralelamente la conectividad hacia el litoral. En este sentido, quienes lo hicieron fueron los caravaneros locales que habían ampliado los símbolos propios, como los rombos escalerados existentes en sus artesanías, incluyendo los peces más representativos que fueron reconocidos en las largas permanencias en el litoral. Una organización socioeconómica tan compleja, ordenada desde los asentamientos agrarios y pecuarios al interior de la costa arreica, no podría interpretarse como respuestas voluntariosas y espontáneas. De acuerdo a la arqueología tardía, como del contacto etnohistórico del siglo XVI, existía una élite que conducía a las comunidades Pica-Tarapacá, tal como fue reconocido por los primeros invasores como: "Caciques", "Curacas" y "Principales" (Trelles 1991).

El manejo de caravanas en los oasis continuó durante el régimen colonial bajo las transformaciones del nuevo modelo mercantilista en la costa arreica (Acosta op. cit.) o en sus propios términos siguiendo los procedimientos ancestrales. Ciertamente, hasta solo algunas décadas, la conexión caravanera altiplano Llica-Pica persistía en armonía con las comunidades locales, aunque los oasis se desvincularon de la costa muy tempranamente a raíz de los impactos de la modernidad decimonónica que ocupara la pampa intermedia y el litoral. Hasta ahora, las observaciones etnográficas indican que las caravanas 
siguen vigentes en las tierras altas (Lecoq 1987; Nielsen 1997-8; Cereceda 2010; Nielsen 2011; Núñez y Nielsen 2011; Gabelman 2015).

En general estos enclaves interétnicos permitían mixturar cultura y biología, estableciendo intercambios de mujeres o creándose vínculos de parentesco carnal y político, multilingüismo y ritualidades compartidas, que en general se infiltraron en la amplia y densa población que constituían las comunidades locales Pica-Tarapacá. En este sentido, los vínculos de tráfico y las diversas modalidades de acceso a recursos complementarios o los tratos a nivel de agencia, se orientaron a formalizar acuerdos consuetudinarios. Perduraban los beneficios mutua- lísticos, sin diluirse las identidades involucradas ni las estructuras de poder de las élites radicadas en distintos parches agrarios (Giddens 1995).

El déficit de subsistencia autárquica y las necesidades de complementariedad social y económica estimularon el control de segmentos productivos a través de espacios internodales. Se configuró finalmente un territorio donde el todo fue la suma de las partes, integradas por una intensa circulación vial con orientaciones pragmáticas y simbólicas. En este escenario del Intermedio Tardío se había percibido la costa y los oasis como un universo indivisible con identidades diferenciadas, pero integradas por idearios comunes de complementariedad y ritualidad.

\section{$\because$ Referencias Citadas}

ACOSTA, J. de. 1940 [1590]. Historia natural y moral de las indias. FCE, México.

ADÁN, L., S. URBINA y M. URIBE. 2007. Arquitectura pública y doméstica en las quebradas de Pica-Tarapacá: asentamiento y dinámica social en el Norte Grande de Chile (900-1450 DC). En Procesos sociales prehispánicos en el sur andino: la vivienda, la comunidad y el territorio, pp. 183-206. Editorial Brujas, Córdoba, Argentina.

AGÜERO, C. 2015. Vestuario y sociedad andina. Desarrollo del Complejo Pica-Tarapacá (800-1400 DC). Ediciones Qillqa Instituto de Arqueología y Antropología, Universidad Católica del Norte, San Pedro de Atacama.

ANGELO, D. yJ. M. CAPRILES. 2000. La importancia de las plantas psicotrópicas para la economía de intercambio y relaciones de interacción en el altiplano sur andino. Complutum 11: 275-284.

ARKUSH, E. y C. STANISH. 2005. Interpreting conflict in the ancient Andes. Current Anthropology 46(1):3-28.

ARKUSH, E.yT.A. TUNG. 2013. Patterns of war in the Andes from the archaic to the late horizon: insights from settlement pattern and cranial trauma. Journal of Archaeological Research 21:307-369.

BARRIGA, V. M. 1955 [1558]. Documentos para la historia de Arequipa, T. III. Arequipa.

BERENGUER, J. 1994. Asentamientos, caravaneros y tráfico de larga distancia en el norte de Chile: el caso de Santa Bárbara. En De costa a selva: intercambio y producción en los Andes centro sur, M. E. Albeck (Ed.), pp. 17-50. Instituto Interdisciplinario de Tilcara, Tilcara, Argentina.
BERENGUER, J. 2006. Gorros del desierto: Headdresses from the Desert. Museo Chileno de Arte Precolombino, Santiago de Chile. (Catálogo de exposición).

BERTRAND, A. 1879. Carta de los desiertos de Tarapacá $i$ de Atacama. (Mapa).

BERTRAND, A. 1885. Memoria sobre la exploración a las cordilleras del Desierto de Atacama (viaje a las cordilleras de Atacama). Imprenta Nacional, Santiago de Chile.

BIBAR, G. de. 1966 [1558]. Crónica y relación copiosa y verdadera de los Reynos de Chile. Fondo Histórico y Bibliográfico J. T. Medina, Editorial Universitaria, Santiago de Chile.

BINDFORD, L. R. 1971. Mortuory practice: their study and their potential. En Approaches to the social dimensions of mortuary practice, J. A. Brow (Ed.), pp. 6-29. Society for American Archaeology, Washington D.C.

BINDFORD, M., A. KOLATA, M. BRENNER, J. JANUSEK, M. SEDDON, M. ABBOT y J. CURTIS. 1997. Climate variations and rise and fall of an Andean civilization. Quaternary Research 47: $235-248$.

BOLLAERT, W. 1975 [1860]. Antiquarian ethnological and other researchers in New Granada, Equator, Peru and Chili, with observations on the pre-incarial, incarial, and other monuments of Peruvian nations. Trübner \& Co., London.

BONNEMAISON, J. 1981. Voyage autour du territoire. L'Espace Géographique 4: 249-262. Paris. 
BRIONES, L. Ms. Archivo regional de geoglifos y rutas prehispánicas. Manuscrito en posesión de los autores.

BRIONES, L., L. NÚÑEZ y V. STANDEN. 2005. Geoglifos y tráfico prehispánico de caravanas de llamas en el desierto de Atacama (Norte de Chile). Chungara. Revista de Antropología Chilena 37(2): 195-223.

CASES, B. 2003. Continuidad y cambio en las bolsas domésticas. Boletín de la Sociedad Chilena de Arqueología 35/36: 28-36.

CASES, B. 2004. Un acercamiento a las bolsas domésticas de Quillagua en relación a las caravanas del periodo Intermedio Tardio (Loa inferior, II Región). Memoria de Título, Departamento de Antropología, Universidad de Chile, Santiago de Chile.

CASES, B. y C. AGÜERO. 2004. Textiles teñidos por amarras del Norte Grande de Chile. Estudios Atacameños 27: 117-138.

CASES, B., C. REES, G. PIMENTEL, R. LABARCA y D. LEIVA. 2008. Sugerencias desde un contexto funerario en un "espacio vacío" del desierto de Atacama. Boletín del Museo Chileno de Arte Precolombino 13(1): 51-70. Santiago de Chile.

CERECEDA, V. 2010. Una extensión entre el altiplano y el mar. Relatos místicos Chipaya y el norte de Chile. Estudios Atacameños. Arqueología y Antropología Surandinas 40: 101-130.

CHAPMAN, A. M. 1976. Puertos de comercio en las civilizaciones Aztecas y Maya. En Comercio y mercado en los imperios antiguos, K. Polanyi, C. M. Arensberg y H. W. Pearson (Eds.), pp. 163-200, Labor Universitaria, Barcelona.

CHAPMAN, R. 2010. Arqueologías de la complejidad. Editorial Bellatierra Arqueología.

CHECURA, J. 1977. Funebría incaica en el Cerro Esmeralda (Iquique, I región). Estudios Atacameños 5: 125-141.

CIEZA DE LEÓN, P. 1962 [1553]. La crónica del Perú. Biblioteca de Autores Españoles 26, España.

CLARKSON, P. B. y L. BRIONES. 2001. Geoglifos, senderos y etnoarqueología de caravanas en el desierto chileno. Boletín del Museo Chileno de Arte Precolombino 8: 35-45. Santiago de Chile.

CÚNEO VIDAL, R. 1915. De algunas etimologías del bajo Collasuyo (Urin Collasuyo) de los incas. Revista Chilena de Historia y Geografía 13(17): 295-305.

GABELMAN, O. 2015. Caminando con llamas, caravanas actuales y analogías para el tráfico e intercambio prehispánico en Bolivia. Estudios Sociales del NOA 15:33-58. Argentina.
GAVIRA, M. C. 2008. Población indígena, sublevación y minería en Carangas: la caja real de Carangas y el mineral de Huantajaya 1750-1804, C. Santoro (Ed.). CIHDE-CODECITE, Universidad de Tarapacá - Instituto Francés de Estudios Andinos, Santiago de Chile.

GEDDA, F. 2001. La última caravana del desierto. Documentos Serie Al Sur del Mundo. Sur Imagen, Santiago de Chile.

GHEGGI, M. S. y V. SELDES. 2012. Evidencias bioarqueológicas de conflicto $c a$. 1000-1432 AD en la quebrada de Humahuaca y el valle Calchaquí. Intersecciones en Antropología 13(1): 103-115. Facultad de Ciencias Sociales, Universidad Nacional del Centro de la Provincia de Buenos Aires, Argentina.

GIDDENS, A. 1995. La constitución de la sociedad: bases para la teoría de la estructuración. Amorrortu Editores, Buenos Aires.

HARRIS, O. 1983. Ecological duality and the roll of the centre in the organization of vertical space in northern Potosí. Ponencia presentada al symposium: An interdisciplinary perspective on Andean Ecological Complementary, Florida.

HIDALGO, J. 1985. Proyectos coloniales inéditos de riego del desierto: Azapa (Cabildo de Arica, 1619); Pampa Iluga (O'Brien, 1765), y Tarapacá (Mendizábal, 1807). Chungara 14: 183-220.

HIDALGO, J. 2000. Dominación y resistencia en el cacicazgo de Pica. Revista de Historia Indígena 4: 49-74.

HIDALGO, J. y G. FOCACCI. 1986. Multietnicidad en Arica, s. XVI. Evidencias etnohistóricas y arqueológicas. Chungara 16-17: 137-147.

HIDALGO, J.yA. DURSTON. 2004 [1999]. Reconstitución étnica colonial en la sierra de Arica: el cacicazgo de Codpa, 1650-1780. En Historia andina en Chile, pp. 507-534. Editorial Universitaria, Santiago de Chile.

HORTA, H. 2000. Diademas de plumas de la costa del norte de Chile: Levidencias de la vestimenta de una posible parcialidad pescadora? Chungara. Revista de Antropología Chilena 32(2): 235243.

LECOQ, P. 1987. Caravanas de lamas, sel et échanges dans communauté de Potosí en Bolivie. Bulletin de l'Institut Français d'Etudes Andines 16:(3-4): 1-38.

LESSA, A. 2004. Ampliación de las discusiones sobre conflictos en el oasis atacameño durante la era de los pukaras: análisis de la muestra esqueletaria de Catarpe-2. Diálogo Andino 27: 9-22. 
LOZANO MACHUCA, J. 1885 [1581]. Carta del Factor de Potosí... al virrey del Perú, en donde se describe la provincia de los Lipes. Relaciones Geográficas de Indias, Perú, vol. 2, Apéndice III. Madrid.

MARTÍNEZ, J. L. 1986. Los grupos indígenas del altiplano de Lipez en la subregión del río Salado. Chungara 16-17: 199-201.

MORAGAS, C. 1991. Antecedentes sobre un pukara de cumbre asociado a un campo de geoglifos y estructuras de cumbre asociado en la quebrada de Tarapacá, área de Mocha, I Región. Boletín del Museo Regional de la Araucanía 4(2): 25-39.

MORAGAS, C. 1995. Desarrollo de las comunidades prehispánicas del litoral de Iquique-desembocadura del río Loa. Actas del XIII Congreso Nacional de Arqueología Chilena. Revista Hombre y Desierto $9(1): 65-80$.

MORAGAS, C. 2015 Ms. Cementerio Pica-Quisma: registros de salvataje. (Manuscrito en posesión de los autores).

MURRA, J. 1972. El control vertical de un máximo de pisos ecológicos en la economía de las sociedades andinas. En Visita de la provincia de León de Huánuco en 1562 por Iñnigo Ortiz de Zúñiga, J. V. Murra (Ed.), vol. 2, pp. 427-468. Universidad Nacional Hermilio Valdizán, Huánuco, Perú.

MURRA, J. 1989. Las funciones del tejido andino en diversos contextos sociales y políticos. En Arte mayor de los Andes, pp. 10-19. Museo Chileno de Arte precolombino, Santiago de Chile.

NIELSEN, A. E. 1997-8. Tráfico de caravanas en el sur de Bolivia: observaciones etnográficas e implicancias arqueológicas. Relaciones de la Sociedad Argentina de Antropología 22-23: 139-178.

NIELSEN, A. E. 2002. Asentamientos, conflicto y cambio social en el altiplano de Lípez (Potosí). Revista Española de Antropología Americana 32: 179-205.

NIELSEN, A. E. 2011. El tráfico de caravanas entre Lípez y Atacama visto desde la cordillera occidental. En En ruta: arqueología, historia y etnografía del tráfico sur andino. L. Núñez y A. Nielsen (Eds.), pp. 83-110. Encuentro Grupo Editor, Córdoba.

NIELSEN, A. E. 2015. El estudio de la guerra en la arqueología surandina. Corpus: Archivos Virtuales de la Alteridad Andina 5. Buenos Aires. http://corpusarchivos.revues.org/1393

NIELSEN, ANCKER. Ms. Notas manuscritas sobre las colecciones de Patillo y Bajo Molle. Manuscrito en posesión de los autores.

NÚÑEZ, L. 1962. Contactos culturales prehispánicos entre la costa y la subcordillera andina. Boletín de la Universidad de Chile 31: 42-47.
NÚÑEZ, L. 1963. Prospección arqueológica en la provincia de Tarapacá. Noticiario Mensual del Museo Nacional de Historia Natural 8:(85-86): 1-9. Santiago de Chile.

NÚÑEZ, L. 1966. Subárea Loa-costa chilena desde Copiapó a Pisagua. Actas y Memoria del XXXVII Congreso internacional de Americanistas, vol. II, pp. 145-182. Buenos Aires, Argentina.

NÚÑEZ, L. 1969. Informe arqueológico sobre una muestra de posible narcótico del sitio Patillos-1 (provincia de Tarapacá, norte de Chile).Arstrysk, pp. 83-95. Etnografisca Museet, Goteborg.

NÚÑEZ, L. 1974. Registro regional de fechas radiocarbónicas del Norte de Chile. Estudios Atacameños 4: 74-126.

NÚÑEZ, L. 1976. Geoglifos y tráfico de caravanas en el desierto chileno. En Volumen de Homenaje al R. P. Gustavo Le Paige, pp. 148-2O2. Universidad del Norte, Antofagasta.

NÚÑEZ, L. 1979. Emergencia y desintegración de la sociedad tarapaqueña: riqueza y pobreza en una quebrada del norte chileno. Atenea 439: 163-213.

NÚÑEZ, L. 1985. Tráfico de complementariedad de recursos entre las tierras altas y el Pacífico en el área centro sur andina. Tesis Doctoral, vol. I y II. Departamento de Antropología Cultural, Universidad de Tokio.

NÚÑEZ, L. 1992. La sociedad tarapaqueña al tiempo de la invasión europea. Campus 3 (20): 60-71. Universidad Arturo Prat, Iquique.

NÚÑEZ, L. Ms. Excavaciones en los oasis de Pica (1959-1961). Manuscrito en posesión de los autores.

NÚÑEZ, L., y J. VARELA, 1967-8. Sobre los recursos de agua y el poblamiento prehispánico de la costa del norte grande de Chile. Estudios Arqueológicos 3-4: 7-41. Universidad de Chile, Antofagasta.

NÚÑEZ, L. y C. MORAGAS. 1976. Una ocupación con cerámica temprana en la secuencia del distrito de Cáñamo (costa desértica del norte de Chile). Estudios Atacameños 5: 21-49.

NÚÑEZ, L. y T. DILLEHAY. 1979. Movilidad giratoria, armonía social $y$ desarrollo en los Andes meridionales: patrones de tráfico e interacción económica (ensayo). Universidad del Norte, Antofagasta.

NÚÑEZ, L. y A. NIELSEN (Eds.). 2011. En ruta:Arqueología, historia y etnografía del tráfico sur andino. Encuentro Grupo Editor, Córdoba, Argentina.

NÚÑEZ, P. 1984. La antigua aldea de San Lorenzo de Tarapacá, Norte de Chile. Chungara 13: 53-66. 
ODONE, M. C. 1994. El tejido de las estrategias de distribución y circulación espacial en Tarapacá: un registro colonial. Revista Memoria Americana 4: 4-78. Universidad de Buenos Aires.

ODONE, M. C. 1995. Quillagua. La descripción de un espacio desde la historia. Actas II Congreso Chileno de Antropología, vol. 2: 598-605. Valdivia.

PACHECO, A. H. 2010. Bioantropología del conflicto. Lesiones esqueletarias en la colección Pica-8 y su relación con situaciones de violencia interpersonales durante el periodo Intermedio Tardio (Región de Tarapacá, Chile). Memoria para optar al título de Antropólogo Físico, Departamento de Antropología, Universidad de Chile, Santiago de Chile.

PACHECO, A. y R. RETAMAL. 2014. Violencia y conflicto en el Intermedio Tardío tarapaqueño de Chile, reflexiones a partir de indicadores osteológicos y arqueológicos. En Indicadores arqueológicos de violencia, guerra y conflicto en Sudamérica, J. López y M. Berón (Eds.), pp. 155-176. Biblioteca Plural, Universidad de la República, Uruguay.

PACHECO, A. y R. RETAMAL. 2015. Avoiding war in Tarapacá (Norte de Chile) during the Andes late intermediate period (AD 1000-1450). International Journal of Osteoarchaeology 27:35-44.

PESTLE, W., C. TORRES-ROUFF, M. HUBBE, F. SANTANA, G. PIMENTEL F. GALLARDO y K. J. KNUDSON. 2015. Explorando la diversidad dietética en la prehistoria del desierto de Atacama: un acercamiento a los patrones regionales. Chungara. Revista de Antropología Chilena 47(2): 201-209.

PETRUZZELLI, B., A. ROBERTS, F. D. PATE, C. M. SANTORO, T. MADDERN, C. CARTER y M. WESTAWAY. 2012. Stable carbon and nitrogen isotopic analysis of skeletal remains from Azapa 71 and Pica-8, Northern Chile: An assessment of human diet and landscape use in the late Holocene. Journal of the Anthropological Society of South Australia 35: 52-80.

PIMENTEL, G. 2009. Las huacas del tráfico. Arquitectura ceremonial en rutas prehispánicas del desierto de Atacama. Boletín del Museo Chileno de Arte Precolombino 14(2): 9-38. Santiago de Chile.

PIMENTEL, G. 2013. Redes viales prehispánicas en el desierto de Atacama: viajeros, movilidad e intercambio. Tesis para optar al grado de Doctor en Antropología, mención Arqueología. Universidad Católica del Norte - Universidad de Tarapacá.

PIMENTEL, G., C. REES, P. DE SOUZA y L. ARANCIBIA. 2011. Viajeros costeros y caravaneros. Dos estrategias de movilidad trasversal del periodo formativo (Desierto de Atacama, Chile). En En ruta: arqueología, historia y etnografía del tráfico surandino, L. Núñez y A. Nielsen (Eds.), pp. 43-81. Encuentro Grupo Editor, Córdoba, Argentina.
ROBB, J. E. 2010. Beyond agency. World Archaeology 42(4): 493520.

ROSTWOROWSKI, M. 1999. Los curacas costeños. Histórica 23:(2): 283-311. Lima.

RYDEN, S. 1947. Archaeological research in the highlands of Bolivia. Elanders Boktryckeri Aktiebolog, Goteborg.

SANHUEZA, J. 1985. Hallazgo de un cementerio prehispánico en la ex oficina salitrera "Yungay Bajo" (Provincia de Iquique, I Región). Nuestro Norte 5: 28-34. Universidad Arturo Prat, Iquique.

SANHUEZA, J. y O. OLMOS. 1981. Usamaya I, cementerio indígena en Isluga, altiplano de Iquique, I Región, Chile. Chungara 8: 169-207.

SANTANA-SAGREDO, F. 2011. Multiculturalidad en el cementerio oriente de Quillagua ¿Coexistencia de grupos culturales? Una aproximación desde la bioantropología mediante un análisis isotópico de dieta y movilidad en el curso inferior del río Loa, periodo Intermedio Tardío. Memoria de título de Antropología Física, Departamento de Antropología, Universidad de Chile, Santiago de Chile.

SANTANA-SAGREDO, F., J. A. LEE-THORP, R. SCHULTING y M. URIBE. 2015. Isotopic evidence for divergent diets and mobility patterns in the Atacama Desert, Northern Chile, during the late intermediate period (AD 900-1450). American Journal of Physical Anthropology 156:374-387.

SHIMADA, M. e I. SHIMADA. 1985. Prehistoric llama breeding and herding on the north coast of Peru. American Antiquity 5O(1): 3-26.

STANDEN, V.y J. SANHUEZA. 1984. Análisis antropológico físico del cementerio Mocha-2 (Norte de Chile, I Región). Estudios Atacameños 7: 237-242.

TORRES-ROUFF, C. y M. A. COSTA. 2006. Interpersonal violence in prehistoric San Pedro de Atacama, Chile: behavioral implications of environmental stress. American Journal of Physical Anthropology 130(1): 60-70.

TORRES-ROUFF, C., W. J. PESTLE y F. GALLARDO. 2012a. Eating fish in the driest desert in the world: osteological and biogeochemical analyses of human skeletal remains from the San Salvador cemetery, North Chile. Latin American Antiquity 23(1): 51-69.

TORRES ROUFF, C., G. PIMENTEL y M. UGARTE. 2012b. ¿Quiénes viajaban? Investigando la muerte de viajeros prehispánicos en el desierto de Atacama (ca. 800 AC - 1536 DC). Estudios Atacameños. Arqueología y Antropología Surandinas 43: 167-186. 
TRELLES, E. 1991. Lucas Martínez Vegazo: funcionamiento de una encomienda peruana inicial. Segunda edición. Fondo Editorial, Pontificia Universidad Católica del Perú, Lima.

URBINA, S. 2007. Sobre espacialidad incaica y planificación hispana: hacia una arqueología colonial de Tarapacá, siglos XV-XVII DC (Norte de Chile). En Actas VI Congreso Chileno de Antropología, Tomo II, pp. 1992-2008. Colegio de Antropólogos A. G., Valdivia.

URBINA, S. y L. ADÁN. 2006. Construcciones de uso público y su distribución en las quebradas tarapaqueñas durante el periodo Intermedio Tardío (900-1450 años DC). Boletín de la Sociedad Chilena de Arqueología 39: 19-34.

URIBE, M. 2006. Acerca de complejidad, desigualdad social y el Complejo cultural Pica-Tarapacá en los Andes centro-Sur (10001450 DC). Estudios Atacameños 31: 91-114.
VÁSQUEZ SÁNCHEZ, V. F., T. E. ROSALES, I. REY FRAILE y G. DORADO. 2012. Pruebas zooarqueológicas e isotópicas de crianza local de camélidos en la zona urbana Moche de los complejos arqueológicos Huacas del Sol y la Luna en Trujillo (Perú). Archaeobios 6(1): 19-32.

VAZQUEZ DE ESPINOSA, A. 1948 [1628]. Compendio y descripción de las indias occidentales. Smithsonian Miscellaneous Collections 108. Smithsonian Institution, Washington.

ZLATAR, V. 1984. Cementerio prehispánico Pica-8. Facultad de Educación y Ciencias Humanas, Instituto de Investigaciones Arqueológicas y Restauración Monumental, Universidad de Antofagasta, Antofagasta.

\section{$*$ Anexo}

Dataciones ${ }^{14} \mathrm{C}$ de sitios del circuito oasis de Pica - costa aledaña

\begin{tabular}{|c|c|c|c|c|c|c|}
\hline SITIO & CLASE & $\mathbf{L A B} / \mathbf{N}^{\circ}$ & MATERIA & DATACIÓNAP & $\begin{array}{c}\text { DATACIÓN } \\
\text { CALIBRADA }\end{array}$ & REFERENCIA \\
\hline Bajo Molle & Cementerio & Geochron & Textil & $749 \pm 75 \mathrm{AP}$ & 1190 a 1402 DC & Moragas 1995 \\
\hline Bajo Molle & Cementerio & Geochron & Músculo humano & $760 \pm 85 \mathrm{AP}$ & 1157 a 1407 DC & Moragas 1995 \\
\hline Bajo Molle & Cementerio & Geochron & Músculo humano & $775 \pm 75 \mathrm{AP}$ & 1162 a $1396 \mathrm{DC}$ & Moragas 1995 \\
\hline Bajo Molle & Cementerio & Geochron & Músculo humano & $1115 \pm 20 \mathrm{AP}$ & 898 a 1022 DC & Moragas 1995 \\
\hline Bajo Molle & Cementerio & Geochron & Músculo humano & $1310 \pm 125 \mathrm{AP}$ & 547 a 1021 DC & Moragas 1995 \\
\hline Pica- 8 & Cementerio & IVIC 172 & Maíz (T6/S-A) & $310 \pm 110 \mathrm{AP}$ & 1445 a S. XVIII & Núñez 1976 \\
\hline Pica-8 & Cementerio & BETA 220924 & $\begin{array}{l}\text { Hueso humano } \\
(\mathrm{BO}-438)\end{array}$ & $810 \pm 40 \mathrm{AP}$ & 1170 a $1280 \mathrm{DC}$ & Uribe et al. 2007 \\
\hline Pica- 8 & Cementerio & IVIC-173 & Textil (T6/S-A) & $1020 \pm 90 \mathrm{AP}$ & 887 a 1257 DC & Núñez 1976 \\
\hline Pica-8 & Cementerio & IVIC-792 & $\begin{array}{l}\text { Tejido humano / } \\
\text { alimento digerido } \\
\left.\text { ( } \mathrm{T}_{7} / \mathrm{S}-\mathrm{G}\right)\end{array}$ & $950 \pm 70 \mathrm{AP}$ & 1017 a 1266 DC & Núñez 1976 \\
\hline Pica-8 & Cementerio & BETA 220923 & $\begin{array}{l}\text { Hueso humano } \\
\qquad(\mathrm{BO}-447)\end{array}$ & $900 \pm 40 \mathrm{AP}$ & 1030 a $1230 \mathrm{DC}$ & Uribe et al. 2007 \\
\hline Pica-8 & Cementerio & BETA 220922 & $\begin{array}{l}\text { Hueso humano } \\
\quad\left(\mathrm{T}_{11} / \mathrm{S}-\mathrm{G}\right)\end{array}$ & $1050 \pm 40 \mathrm{AP}$ & 900 a $1030 \mathrm{DC}$ & Uribe et al. 2007 \\
\hline Pan de Azúcar-2 & Campamento & BETA 150708 & Coprolito llamas & $450 \pm 40 \mathrm{AP}$ & 1430 a 1460 DC & Briones et al. 2005 \\
\hline Cerro Mono-1 & $\begin{array}{l}\text { Inhumación } \\
\text { individual }\end{array}$ & BETA 150707 & Músculo humano & $3110 \pm 40 \mathrm{AP}$ & 1420 a $1380 \mathrm{AC}$ & Briones et al. 2005 \\
\hline Cerro Pintados-3 & Campamento & 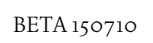 & Maíz/marlo & $970 \pm 50 \mathrm{AP}$ & 990 a 1180 DC & Briones et al. 2005 \\
\hline Soronal-3 & $\begin{array}{l}\text { Campamento } \\
\text { depósito } \\
\text { estratificado }\end{array}$ & 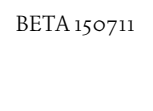 & Carbón & $1450 \pm 40 \mathrm{AP}$ & 650 a $980 \mathrm{DC}$ & Briones et al. 2005 \\
\hline
\end{tabular}

